\title{
Historic American Apple Cultivars: Identification and Availability
}

\author{
Gayle M. Volk ${ }^{\mathbf{1}}$ and Adam D. Henk \\ USDA-ARS National Center for Genetic Resources Preservation, 1111 S. Mason Street, Fort Collins, \\ CO 80521
}

\begin{abstract}
AdDitional INDEX words. early American, fruit, historic, Malus, orchards
Abstract. Apples (Malus Mill.) have been economically and socially important throughout the centuries in North America. Apple cultivar (Malus $\times$ domestica Borkh.) collections that include historic cultivars are valued for their unique diversity, historical significance, and also as a resource to identify unknown trees; however, not all of the historically significant apple cultivars are currently included in these collections. We used historic books, publications, and nursery catalogs to develop an inventory of apple cultivars that were propagated and grown in the United States before 1908. We collected synonym, introduction date, and original source country information for 891 historic apple cultivars. Most of the historic American cultivars originated as seedlings first planted in the United States. Some cultivars were brought to the United States from the United Kingdom, France, Russia, Germany, and other European countries. We classified historic apple cultivars based on their availability over time and popularity in nursery catalogs. Ninety percent of the most popular historic apple cultivars in the United States were available in 2015 in the U.S. and U.K. national collections and within several commercial and private collections. This work identified high priority historic cultivars that are not currently protected within genebanks that could be added to genebank collections in the future.
\end{abstract}

\section{"It is remarkable how closely the history of the Apple-tree is connected with that of man." (Thoreau, 1913)}

Apple has been a mainstay of American culture for centuries (Burford, 2013). Wild Malus sp. are native to North America as well as Europe and Asia (Volk et al., 2015). The wild apple species of North America [Malus fusca (Raf.) C.K. Schneid., Malus angustifolia (Aiton) Michx., Malus coronaria (L.) Mill., and Malus ioensis (Alph. Wood) Britton] were traditionally used by Native Americans for food, medicinal purposes, tools, fuel, and shelter (Turner and Hebda, 1990; Turner and Turner, 2008; Yanovsky, 1936). Europeans brought seeds, scionwood, or trees of their local apple cultivars with them to North America during the colonial era (Dolan, 2009). The grafted trees that originated from the European scions were genetically identical to those in Europe, and thus their cultivar names were retained (Dolan, 2009).

Seeds brought from Europe were planted and grew into seedling trees, which were not identical to their original European sources. Seeds were from open-pollinated crosses, resulting in recombination events which revealed new genetic combinations of inherited traits (Dolan, 2009). Early colonists collected seeds from apple trees and planted them widely (Dolan, 2009; Morgan and Richards, 1993). The planting of seedlings was encouraged, as apple trees provided both food and beverage to new settlers on their homesteads (Hokanson et al., 1997). Sometimes, specific desirable trees were identified from these seedling populations and were subsequently clonally propagated, distributed, and planted. New cultivars

Received for publication 1 Jan. 2016. Accepted for publication 25 Mar. 2016. The authors appreciate the manuscript reviews provided by Drs. Peter Bretting and Chris Richards.

Mention of trade names or commercial products or companies in this article is solely for the purpose of providing specific information and does not imply recommendation or endorsement by the U.S. Department of Agriculture.

${ }^{1}$ Corresponding author. E-mail: gayle.volk@ars.usda.gov. with physiological traits adapted to regional climates were identified (Diamond, 2010; Dolan, 2009). Some of the earliest named apple cultivars originating in the United States were High Top Sweet, Roxbury Russet, and Rhode Island Greening, all dating from the early to mid-1600s (Smith, 1971).

In colonial times, apples were valued for their use in hard cider production perhaps more so than for their value as dessert or cooking apples (Juniper and Mabberley, 2006). People vary in their preference for apple fruit sweetness, acidity, juiciness, and crispness (Bonany et al., 2014; Harker et al., 2003), and traits such as flavor and crispness are the most important traits rated by producers for successful apple cultivars (Yue et al., 2013). Historic apple cultivars differ in their fruit trait characteristics and offer novelty to the marketplace. Novel cultivars, whether heirloom or new, attract markets that make fruit production profitable (Yue and Tong, 2011).

"I love better to go through the old orchards of ungrafted appletrees, at whatever season of the year,-so irregularly planted: sometimes two trees standing close together; and the rows so devious that you would think that they not only had grown while the owner was sleeping, but had been set out by him in a somnambulic state." (Thoreau, 1913)

A recent resurgence in appreciation for heritage fruits and vegetables has brought about an interest in historic apple cultivars that were once valued for cider, fresh consumption, and processing (Hansen, 2010). There is a growing segment of the population that chooses to plant and consume heirloom fruits and vegetables (Grassbaugh et al., 2004; Merwin 2008). Although many historic fruit cultivars have been identified and are available, the search for additional historic fruit cultivars continues (Veteto and Carlson, 2014). Heirloom fruit can be found in fruit growing regions at local farmer's markets and in many backyards (Goland and Bauer, 2004; Merwin, 2008).

The interest in historic apple cultivars is from both cultural and historical perspectives as federal (national parks and 
monuments), state, and private landholders seek to learn more about local historic fruit trees (Routson et al., 2009). In some cases, original apple trees from the late 1800s may still be alive, but cultivar identity documentation has often been lost. Increasingly, there is an interest in identifying the cultivars represented by historic fruit trees (Routson et al., 2009). To identify unknown trees, it is necessary to have authentic apple cultivars available for phenotypic and genetic comparisons (Routson et al., 2009).

The U.S. Department of Agriculture (USDA), Agricultural Research Service National Plant Germplasm System (NPGS) maintains one of the largest, most diverse ex situ apple collections in the world (Volk et al., 2015). Malus $\times$ domestica cultivars (1473 accessions), as well as thousands of individuals representing hybrids and wild species, are maintained in the field collection of the Plant Genetic Resources Unit (PGRU) in Geneva, NY (Volk et al., 2015). Given the maintenance costs and space limitations, genebank collections cannot conserve every cultivar that has ever been named or described (van Treuren et al., 2009, 2010; Volk et al., 2015). Consequently, the focus of the NPGS collection is to conserve genetic diversity, in the forms of alleles, genotypes, and specific traits, as well as cultivars that are of key interest to apple breeding and research programs (Volk et al., 2015; Walters et al., 2008). It is a challenge for genebanks to determine the authenticity and novelty of their holdings (van de Wouw et al., 2011).

Apple is often cited as a prominent example of crop genetic erosion in the United States based on the large number of named cultivars recorded historically compared with those currently available (Fowler and Mooney, 1990). Etymological variation in cultivar names does not necessarily correspond strongly to genetic variation and identity (Bellon and Brush, 1994; Jarvis et al., 2008; Quiros et al., 1990; Sadiki et al., 2007). Nonetheless, without the means for genetically analyzing currently unavailable cultivars, the historical records of cultivar existence provide a valuable indication of the extent of historical cultivar availability (Börjeson, 2015; Mack, 1991; Pincetl et al., 2013), and can provide some rough index, within very broad limits, of the relative quantity of cultivar diversity currently available relative to that in historical eras (Solberg and Breian, 2015). The presence of cultivar listings in historical records can serve as a potentially useful tool for gauging the historical importance of such cultivars (Börjeson, 2015; Zeven and Brandenburg, 1986). This follows from the assumption that, if a cultivar is recorded historically many times, then it was more widely grown and may have met many horticultural needs and yielded valuable products, and thus possessed important genetic traits. Conversely, if a cultivar name is recorded once or only a few times, perhaps it was not cultivated widely or for very long, and therefore was less important agronomically or as a source of genetic diversity. Therefore, cultivars that were frequently mentioned throughout long periods of the historical record would be assigned the highest priorities for conservation in genebanks and those recorded rarely during brief period would have lesser priority.

Recognizing a need for access to key historical apple cultivars in genebanks, we used books and nursery catalogs to identify historically significant apple cultivars in the United States. We then developed criteria to classify these cultivars based on their popularity and longevity, and queried apple collection inventories to obtain information about cultivar availability in 2015 .

\section{Materials and Methods}

Cultivar inventories were compiled primarily from books and historic nursery catalogs. Information for apple cultivars from early American eras (1600s to 1830) was gathered from books (Chappell, 2000; Hatch, 1998; Morgan and Richards, 1993) as well as historic references that were downloaded from online sources, including the National Agricultural Library (Supplemental Table 1). Ten references provided information for the period from 1736 to 1810 (with between 14 and 102 cultivars listed in each). Apple cultivar listings for the mid1800s (1830 to 1869) were compiled from four source books [with between 11 and 122 cultivars listed in each (Supplemental Table 1)].

Forty-nine nursery catalogs that advertised apple cultivars dating between 1870 and 1907 (between 11 and 129 cultivars listed in each) were downloaded from online sources, including the National Agricultural Library (Supplemental Table 1). Two additional books provided information across the eras (Morgan and Richards, 1993; Warder, 1867). A comprehensive book "Nomenclature of the apple: A catalogue of the known cultivars referred to in American publications from 1804 to 1904" (Ragan, 1905) was used to determine, which apple cultivars were present in the United States within that time period but had originated from other countries.

Apple cultivars in the compiled lists were cross referenced to identify synonyms according to the National Fruit Collection, Brodgale, UK (NFC, 2015), Smith (1971), Calhoun (2010), and historic nursery catalogs (Supplemental Table 1), and standardized names were recorded for the identified synonyms. Many additional synonyms exist for cultivars, but our work focused on standardizing names that were recorded in the surveyed literature rather than documenting all known synonyms for apple cultivars.

The NPGS online database Germplasm Resources Information Network (USDA, 2015) was queried using standardized names and historic synonyms to assess collection availability for apple cultivars. For accessions not available in the NPGS, the NFC database was queried (NFC, 2015). For cultivars that were not available in either collection, the inventory of the Temperate Orchard Conservancy, Molalla, OR (Temperate Orchard Conservancy, 2016), the cultivar list provided in Veteto and Carlson (2014), that available for Tower Hill Botanic Garden (Boylston, MA), as well as commercial nurseries (Albemarle CiderWorks, North Garden, VA; Greenmantle Nursery, Garberville, CA; Kuffel Creek Apple Tree Nursery, Riverside, CA; Salt Spring Apple Co., Salt Spring Island, BC, Canada; Urban Homestead, Bristol, VA) were queried.

Original introduction dates and source countries for each apple cultivar were gathered from Smith (1971), USDA (2015), and Calhoun (2010). For each cultivar, the earliest documented date was recorded. Data for the most recent recorded date of each cultivar were gathered from Smith (1971), from the most recent reference in the historical literature, or was recorded as 2015 for materials that were in the inventories of the NPGS, NFC, or available from commercial or nonprofit organizations. Cultivar durations were calculated by subtracting the earliest documented date from the date of the most recent documented occurrence of each cultivar. 
The apple cultivars inventoried in this work were categorized according to introduction dates based on published records. The categories were early [EARLY (before 1830)], mid-1800s [MID (1830-69)], and century [CEN (1870-1907)]. These ranges were established based on gaps in time for which source information that was available. The earliest recorded introduction date was the basis for the first categorization factor (EARLY, MID, and CEN). If the cultivar was subsequently mentioned in literature in another time period, the second (or third) descriptor name was added to the first classification. For example, if a cultivar was documented pre-1830, and then subsequently documented in the mid-1800s, it was listed as EARLY-MID. If this same cultivar was also listed in a 1900 nursery catalog, it was classified as EARLY-MID-CEN. If a cultivar was first listed as MID, and was also listed in the 1900 nursery catalog, it was classified as MID-CEN.

The American Pomological Society (APS) was a society of pomologists with some members who were experts in apple cultivation. APS membership provided recommendations in 1905 based on experience with "practical growers who have tested them in various sections of the country." APS sent inquiries to fruit growers for feedback on cultivars with desirable qualities. It was noted that some growers considered only fruit quality in their responses, whereas others considered tree hardiness, fruitfulness under varying conditions, and commercial value. Responses were compiled and published (Ragan, 1909). We appended the abbreviation "-APS" after the time period categorization of the cultivar (or a synonym for that cultivar) was listed in the 1909 APS published recommendations. Cultivars that were listed in the APS publication (Ragan, 1909), but not found in the surveyed literature, were listed as "APS" in our classification system.

Longevity and popularity were used as criteria to classify each apple cultivar. Category 1 cultivars were defined as those that were present in at least 10 of the 49 nursery catalogs dated between 1888 and 1907. The EARLY-MID-CEN and

Table 1. Number of historic American apple cultivars classified according to introduction date EARLY (before 1830), MID (1830-69), or CEN (1870-1907). American Pomological Society (APS) designation indicates if the cultivar (or a synonym) is listed as recommended by APS in 1909. The rightmost column indicates the number of apple cultivars in each category that were listed in 10 or more catalogs (of the 49 surveyed) between 1888 and 1907.

\begin{tabular}{lcccrr}
\hline & \multicolumn{3}{c}{ Cultivars (no.) } \\
\cline { 2 - 6 } Category & Not in APS (1909) & In APS (1909) & Only APS (1909) & Total & $10+$ catalogs (1888-1907) \\
\hline EARLY & 163 & 7 & & 170 & 51 \\
EARLY-MID & 38 & 13 & & 104 & 0 \\
EARLY-MID-CEN & 25 & 79 & 17 & 303 & 31 \\
MID & 272 & 14 & & 84 & 0 \\
MID-CEN & 15 & 69 & 56 & 179 & 11 \\
CEN & 82 & 41 & 73 & 891 & 93 \\
Total & 595 & 223 & & \\
\hline
\end{tabular}

Table 2. Availability of historic apple cultivars in 2015 presented by both number (A) and percent (B). The sources were queried in the following order to determine availability: U.S. Department of Agriculture, Agricultural Research Service National Plant Germplasm System (NPGS); National Fruit Collection (NFC, Brodgale, UK); Temperate Orchard Conservancy (TOC, Molalla, OR); commercial sources [Tower Hill Botanic Garden (Boylston, MA), Greenmantle Nursery (Garberville, CA), Urban Homestead (Bristol, VA), Kuffel Creek Apple Tree Nursery (Riverside, CA), Albemarle CiderWorks (North Garden, VA), Salt Spring Apple Co. (Salt Spring Island, BC, Canada)]; and Veteto and Carlson (2014).

\begin{tabular}{|c|c|c|c|c|c|c|c|c|}
\hline \multirow[b]{2}{*}{ A } & \multicolumn{8}{|c|}{ Cultivars (no.) } \\
\hline & Total & NPGS & NFC & TOC & Commercial & Veteto and Carlson (2014) & Total available & Unavailable \\
\hline$\overline{\text { Category } 1^{z}}$ & 150 & 84 & 16 & 31 & 2 & 2 & 135 & 15 \\
\hline Category $2^{\mathrm{y}}$ & 101 & 25 & 12 & 24 & 3 & 2 & 66 & 35 \\
\hline \multirow[t]{2}{*}{ Category $4^{\mathrm{w}}$} & 589 & 39 & 22 & 60 & 3 & 6 & 130 & 459 \\
\hline & \multicolumn{8}{|c|}{ Cultivars (\%) } \\
\hline Category $2^{\mathrm{y}}$ & 25 & 12 & 24 & & 6 & 2 & 65 & 35 \\
\hline Category $3^{\mathrm{x}}$ & 20 & 12 & 24 & & 0 & 0 & 55 & 45 \\
\hline Category $4^{\mathrm{w}}$ & 7 & 4 & 10 & & 1 & 1 & 22 & 78 \\
\hline
\end{tabular}

${ }^{\mathrm{z}}$ Category 1 apple cultivars were present in at least 10 of the 49 nursery catalogs dated between 1888 and 1907 or identified in at least three time periods in the literature (before 1830, between 1830 and 1869, and between 1870 and 1907).

${ }^{y}$ Category 2 cultivars were identified in the literature in at least two time periods (either before 1830 and between 1830 and 1869 , or between 1830 and 1869 and between 1870 and 1907).

${ }^{\mathrm{x}}$ Category 3 cultivars were only found in the literature in one time period (before 1830, between 1830 and 1869 , or between 1870 and 1907 ) and were also recommended by the American Pomological Society (APS).

${ }^{\text {w }}$ Category 4 cultivars were found only in the literature in one time period (before 1830, between 1830 and 1869 , or between 1870 and 1907 ) but were not included in the APS recommendations. Category 4 cultivars were also those that were listed in the APS recommendations, but not documented in the literature. 
EARLY-MID-CEN-APS cultivars were also placed into category 1 . Category 2 cultivars were defined as those that were classified as EARLY-MID, MID-CEN, EARLY-MIDAPS, or MID-CEN-APS. Category 3 cultivars were those that were listed in a single era, and were also recommended by APS (EARLY-APS, MID-APS, CEN-APS). Category 4 cultivars were those listed for a single era (EARLY, MID, CEN) but were not on the list recommended by APS. Category 4 cultivars were also cultivars that were recommended by APS but not listed in any of the literature that was surveyed (APS).

All data were recorded in Excel 2010 (Microsoft, Redmond, WA) and displayed using Excel 2010 and SigmaPlot 11.0 (Systat Software, San Jose, CA).

\section{Results}

Apple cultivar lists were compiled from 66 documents (Supplemental Table 1). The 3687 apple cultivar entries were organized into 891 standardized names. Of these 891 names, 706 did not have any synonyms, 95 had a single synonym, 37 had two synonyms, 18 had three synonyms, 15 had four synonyms, and 20 had between 5 and 16 synonyms (Supplemental Table 2).

The most frequently mentioned cultivars in the literature and catalogs that were inventoried were Ben Davis (60 citations), Early Harvest (57 citations), Yellow Bellflower (55 citations), Golden Russet (51 citations), Red Astrachan (48 citations), Duchess of Oldenburg (47 citations), Winesap (46 citations), Rhode Island Greening (41 citations), Jonathan (39 citations), Wealthy (38 citations), and Yellow Transparent (38 citations).

The numbers of cultivars in each of the classification categories are provided in Table 1. In our dataset, 325 cultivars originated in the EARLY time period, 370 cultivars originated in the MID time period, and 123 cultivars originated in the CEN time period (Table 1). Of these, 99 of the EARLY, 83 of the MID, and 41 of the CEN cultivars were recommended by APS in 1908 (Table 1). Introduction dates were not available for 73 cultivars that were only listed by APS.

A total of 331 unique apple cultivars were listed in 49 nursery catalogs dated from 1888 to 1907 . Ninety-three of these apple cultivars were listed in more than 10 of the 49 nursery catalogs. These 93 cultivars originated in the following eras: EARLY (51 cultivars), MID (31 cultivars), and CEN (11 cultivars), and all were recommended by APS (Table 1).

Category Classification. The 891 apple cultivars were classified into four categories using cultivar longevity and popularity to target cultivars for acquisition and conservation. Category 1 included 150 apple cultivars. Category 2 included 101 cultivars and 51 cultivars were placed into the third category (Table 2). There were 589 cultivars placed into the fourth category.

By definition, category 1 cultivars had many citations, but hundreds of the documented cultivars had only a single citation, and most of these were classified as category 4 cultivars (Fig. 1). The mean duration $( \pm \mathrm{SE})$ for category $1,2,3$, and 4 cultivars was $201 \pm 8,206 \pm 18,96 \pm 10$, and $50 \pm 3$ years, respectively (Fig. 2).

WhERE DID U.S. APPLES COME FROM? Of the cultivars classified as EARLY, $56 \%$ originated as seedlings in the United States (Fig. 3). The remaining cultivars that were classified as EARLY were imported as scions or trees into North America

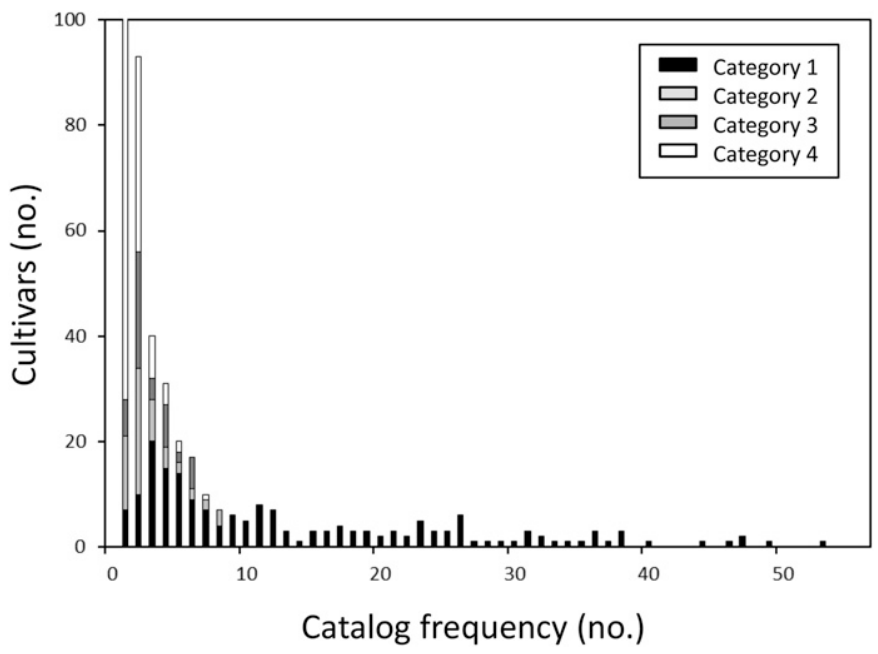

Fig. 1. The number of apple cultivars (separated by category) and their frequency of citations in the literature [71 references (Supplemental Table 1)]. The bar for catalog frequency $=1$ extends to 527 cultivars. Category 1 apple cultivars were present in at least 10 of the 49 nursery catalogs dated between 1888 and 1907 or identified in at least three time periods in the literature (before 1830, between 1830 and 1869, and between 1870 and 1907). Category 2 cultivars were identified in the literature in at least two time periods (either before 1830 and between 1830 and 1869, or between 1830 and 1869 and between 1870 and 1907), Category 3 cultivars were only found in the literature in one time period (before 1830, between 1830 and 1869 , or between 1870 and 1907) and were also recommended by the American Pomological Society [APS (Ragan, 1909)]. Category 4 cultivars were found in the literature in one time period (before 1830 , between 1830 and 1869 , or between 1870 and 1907), but were not included in the APS recommendations. Category 4 cultivars were also those that were listed in the APS recommendations, but not documented in the literature.

from Europe and Russia in the 1600 s to early 1800 s. Our work identified 83 apple cultivars available in 2015 that were imported as scions in the EARLY time period. These apple cultivars were from the United Kingdom (43 cultivars), France (15 cultivars), Russia/Former Soviet Union (5 cultivars), Germany (5 cultivars), and other European countries (10 cultivars). Five EARLY cultivars originated in Canada (Table 3; Fig. 4A). Eleven of the EARLY cultivars available in 2015 did not have known source countries.

Information compiled from the listings provided by Ragan (1905) for apple cultivars present in the United States between 1804 and 1904 revealed an influx of apple cultivar imports from Russia (Ragan, 1905). The large number of Russian cultivar imports was in part due to an introduction of Russian winterhardy apples for use in the Great Plains by USDA and the Iowa Agricultural College in 1870 (Gibb, 1884). According to Ragan (1905), 1095 apple cultivars grown in the United States originated from Russia (424 cultivars), United Kingdom (387 cultivars), Canada ( 70 cultivars), France (68 cultivars), Germany (45 cultivars), Belgium (16 cultivars), and other European countries (85 cultivars) (Fig. 4B).

Current availability of Cultivars. As of 2015, NPGS maintained living trees of $56 \%, 25 \%, 20 \%$, and $7 \%$ of the apple cultivars that were classified as category $1,2,3$, and 4 , respectively. When the NFC was included in the analyses, availability proportions rose to $67 \%, 37 \%, 32 \%$, and $11 \%$ for the category $1,2,3$, and 4 cultivars, respectively. When organizations such as the Temperate Orchard Conservancy and the information within Veteto and Carlson (2014), as well as commercial nurseries were considered, the proportion of 
category 1, 2, 3, and 4 cultivars that were available in 2015 increased to $90 \%, 65 \%, 55 \%$, and $22 \%$, respectively (Table 3 ). In all, 135 of the 150 category 1 cultivars, 66 of the 101 category 2 cultivars, 28 of the 51 category 3 cultivars, and 130 of the 589 category 4 cultivars were found to be available in 2015 in the U.S. and U.K. genebanks and within the queried commercial and private collections in the United States (Table 3 ). There are more category 4 cultivars that are unavailable, compared with the number of category 1, 2, and 3 cultivars

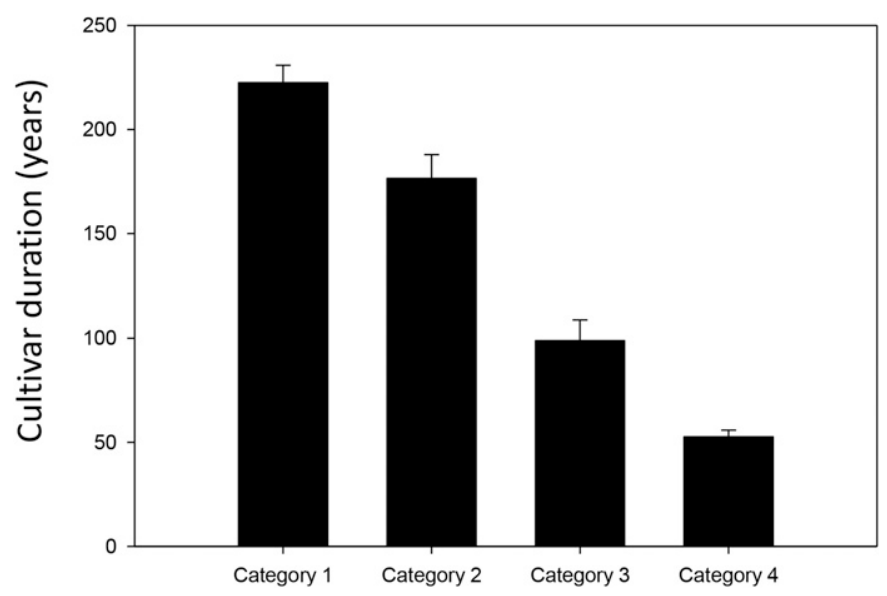

Fig. 2. Average duration of apple cultivar availability (with SE) calculated by subtracting the introduction date from the most recent recorded date for each cultivar. Category 1 apple cultivars were present in at least 10 of the 49 nursery catalogs dated between 1888 and 1907 or identified in at least three time periods in the literature (before 1830, between 1830 and 1869, and between 1870 and 1907). Category 2 cultivars were identified in the literature in at least two time periods (either before 1830 and between 1830 and 1869, or between 1830 and 1869 and between 1870 and 1907), Category 3 cultivars were only found in the literature in one time period (before 1830 , between 1830 and 1869 , or between 1870 and 1907) and were also recommended by the American Pomological Society [APS (Ragan, 1909)]. Category 4 cultivars were found only in the literature in one time period (before 1830, between 1830 and 1869 , or between 1870 and 1907) but were not included in the APS recommendations. Category 4 cultivars were also those that were listed in the APS recommendations, but not documented in the literature.

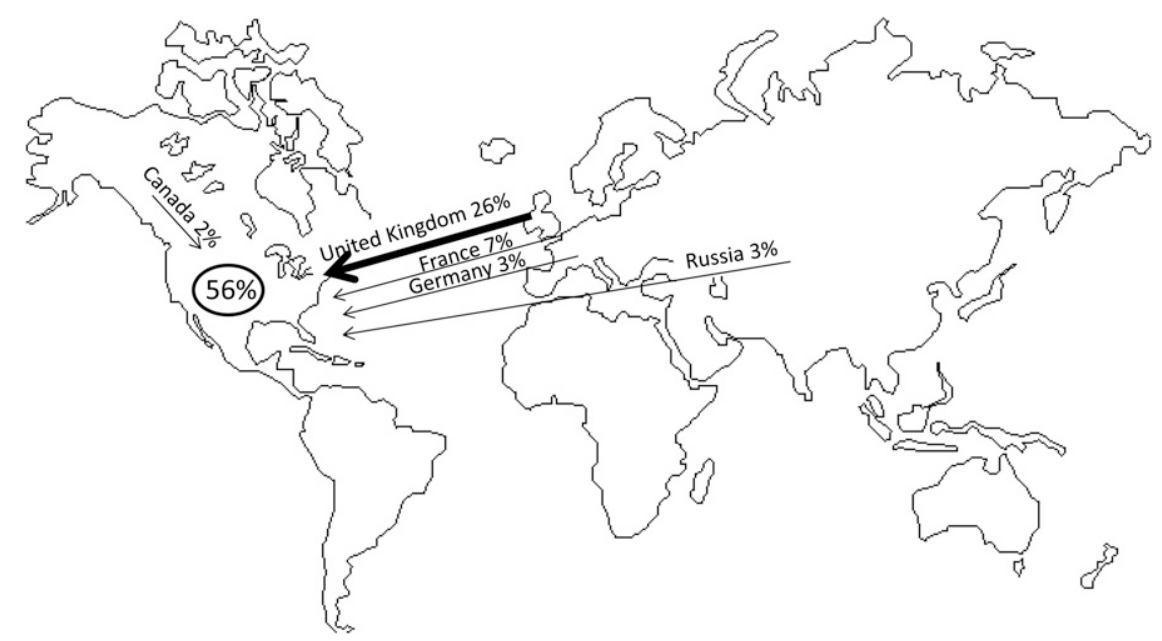

Fig. 3. World map depicting the original source of apple cultivars that were grown in the United States before 1830. Country contributions of $2 \%$ or greater are shown. Fifty-six percent of the apple cultivars grown in the United States before 1830 originated as seedlings in the United States The arrow is thickest for the United Kingdom, which was the source of the largest percentage of imported apple cultivars. that are unavailable. Those cultivars were only minimally documented in the historic literature and might not have been actively propagated as clones or distributed through nurseries (Fig. 5). Alternatively, some of these cultivar names might be synonymous with more widespread, prominent cultivars.

Of the 156 EARLY cultivars (both originating in the United States and elsewhere), 14 of the category 1 cultivars, 17 of the category 2 cultivars, 3 of the category 3 cultivars, and 122 of the category 4 cultivars were not available in NPGS, NFC, or from the commercial and private sources in the United States that were queried (Supplemental Table 2). The unavailable cultivars might still be available through other genebanks, public, or private collections.

\section{Discussion}

"Not if I had a hundred tongues, a hundred mouths, An iron voice, could I describe all the forms And reckon up all the names of these wild apples." (Thoreau, 1913)

In the United States, hundreds of thousands of seedling apple trees were planted between 1600 and 1905 for juice (to be made into hard cider) and fruit consumption (Dolan, 2009). A small fraction of these apple trees were named and/or recorded in various regional contests focused on finding new apple cultivars of interest. Still fewer of these trees were propagated, sold, and recognized as new desirable cultivars originating in North America (Diamond, 2010). We sought to identify apple cultivars with potential historical significance by documenting the presence of the names of apple cultivars over time and their frequency of mention in nursery catalogs. This strategy has its limitations because it is based on available documentation; however, it provides insights into the apple cultivars that were once widely available. Although we recognize that our work is not exhaustive, we believe our work is sufficiently thorough to identify primary historic American cultivars. It is likely that some historically significant apple cultivars have been omitted from our analyses or misclassified due to the information that was available. Future efforts that make use of additional historical sources will likely reveal additional cultivars of interest.

Patterns in the persistence of named cultivars do not directly measure the degree of genetic diversity that existed because many names may represent synonyms (Gross et al., 2012; van Treuren et al., 2010). A study by the Rural Advancement Foundation International (RAFI) in 1982 (cited by Fowler and Mooney, 1990; Heald and Chapman, 2016) determined that, of the 7098 apple cultivars found between 1804 and 1904 in the United States (Ragan, 1905), $6121(86 \%)$ were not available in NPGS in 1983. The RAFI study did not take into account synonymous cultivar names or the agronomical/ historical importance of the cultivars that were named, and was likely an overestimation of the cultivars 
Table 3. Apple cultivars that were introduced to the United States before 1830 in the form of scions or trees that are currently available (based on name). Category ranks 1-4 were determined based on persistence in the literature and frequency of presence in nursery catalogs between 1888 and 1907. Availability was determined by presence in the online inventories of the U.S. Department of Agriculture, Agricultural Research Service National Plant Germplasm System (NPGS), National Fruit Collection (NFC, Brodgale, UK), and Temperate Orchard Conservancy (TOC, Molalla, OR).

\begin{tabular}{|c|c|c|c|c|c|}
\hline Cultivar & Source & Origin yr & Category rank ${ }^{z}$ & Category classification & Current availability \\
\hline Acklam Russet & England & 1768 & 4 & EARLY & NFC \\
\hline Alexander & Russia & 1700 & 1 & EARLY-MID-CEN-APS & NPGS \\
\hline Antonovka & Russia & 1826 & 3 & EARLY-APS & NPGS \\
\hline Autumn Pearmain & England & 1590 & 2 & EARLY-MID & NFC \\
\hline Baumann's Reinette & Belgium & 1811 & 2 & EARLY-MID & NPGS \\
\hline Baxter & Canada & 1800 & 1 & EARLY-MID-CEN-APS & NPGS \\
\hline Beauty of Kent & England & 1820 & 1 & EARLY-MID-CEN-APS & NFC \\
\hline Belle de Boskoop & The Netherlands & 1782 & 1 & EARLY-MID-CEN & NPGS \\
\hline Blenheim Orange & United Kingdom & 1740 & 2 & EARLY-MID-APS & NPGS \\
\hline Boiken & Germany & 1828 & 1 & EARLY-MID-CEN-APS & NPGS \\
\hline Borsdorf & Germany & 1500 & 1 & EARLY-MID-CEN & NFC \\
\hline Brown Pippin & United Kingdom & 1782 & 4 & EARLY & NPGS \\
\hline Burr Apple & England & 1782 & 4 & EARLY & NFC \\
\hline Calville Blanc d'Hiver & France & 1598 & 2 & EARLY-MID & NPGS \\
\hline Calville Rouge d'Ete & France & 1810 & 4 & EARLY & TOC \\
\hline Canada Reinette & France & 1771 & 1 & EARLY-MID-CEN-APS & NFC \\
\hline Cat's Head & England & 1600 & 4 & EARLY & NFC \\
\hline Charlamoff & Former Soviet Union & 1700 & 1 & EARLY-MID-CEN-APS & NPGS \\
\hline EARLYes Quince & United Kingdom & 1782 & 1 & EARLY-MID-CEN-APS & NPGS \\
\hline Cornish Aromatic & United Kingdom & 1782 & 2 & EARLY-MID & NPGS \\
\hline Courpendu Bardin & France & 1667 & 4 & EARLY & NFC \\
\hline Court of Wyck & England & 1790 & 2 & EARLY-MID & NFC \\
\hline Court pendu plat & United Kingdom & 1613 & 4 & EARLY & NPGS \\
\hline Cox's Orange Pippin & United Kingdom & 1825 & 1 & EARLY-MID-CEN & NPGS \\
\hline Devonshire & England & 1754 & 4 & EARLY & NFC \\
\hline Dutch Codlin & The Netherlands & 1782 & 2 & EARLY-MID & NFC \\
\hline Eight Square & Ireland & 1782 & 4 & EARLY & NFC \\
\hline Fameuse & Canada & 1730 & 1 & EARLY-MID-CEN-APS & NPGS \\
\hline Fenouillet Rouge & France & 1667 & 4 & EARLY & NFC \\
\hline Flanders Pippin & France & 1782 & 4 & EARLY & NPGS \\
\hline Foxwhelp & United Kingdom & 1664 & 4 & EARLY & NPGS \\
\hline French Crab & France & 1754 & 4 & EARLY & NPGS \\
\hline French Pippin & Ireland & 1755 & 1 & EARLY-MID-CEN-APS & NPGS \\
\hline Gilliflower & United Kingdom & 1629 & 1 & EARLY-MID-CEN & NPGS \\
\hline Gloria Mundi & Germany & 1769 & 1 & EARLY-MID-CEN & NPGS \\
\hline Golden Harvey & United Kingdom & 1600 & 2 & EARLY-MID & NPGS \\
\hline Golden Pippin & Ireland & 1735 & 1 & EARLY-MID-CEN-APS & NPGS \\
\hline Golden Reinette & Europe & 1600 & 4 & EARLY & NFC \\
\hline Golden Russet & United Kingdom & 1714 & 1 & EARLY-MID-CEN-APS & NPGS \\
\hline Gravenstein & Denmark & 1669 & 1 & EARLY-MID-CEN-APS & NPGS \\
\hline Hawthornden & Scotland & 1780 & 2 & EARLY-MID & NFC \\
\hline Herefordshire Pearmain & United Kingdom & 1200 & 2 & EARLY-MID & NPGS \\
\hline Herefordshire Red Streak & England & 1798 & 4 & EARLY & TOC \\
\hline Irish Peach & Ireland & 1820 & 1 & EARLY-MID-CEN-APS & NPGS \\
\hline Jungferen & Germany & 1736 & 4 & EARLY & NPGS \\
\hline Kentish Fill Basket & England & 1782 & 4 & EARLY & NFC \\
\hline Keswick's Codlin & England & 1793 & 1 & EARLY-MID-CEN-APS & NFC \\
\hline King of the Pippins & England & 1800 & 4 & MID & NFC \\
\hline Lady & France & 1628 & 1 & EARLY-MID-CEN-APS & NPGS \\
\hline Lady Finger & France & 1893 & 1 & EARLY-MID-CEN & TOC \\
\hline Lemon Pippin & United Kingdom & 1700 & 2 & EARLY-MID & NPGS \\
\hline London Pippin & United Kingdom & 1580 & 1 & EARLY-MID-CEN & NPGS \\
\hline Margaret & United Kingdom & 1665 & 1 & EARLY-MID-CEN-APS & NPGS \\
\hline Margil & United Kingdom & 1750 & 2 & EARLY-MID & NPGS \\
\hline
\end{tabular}


Table 3. Continued.

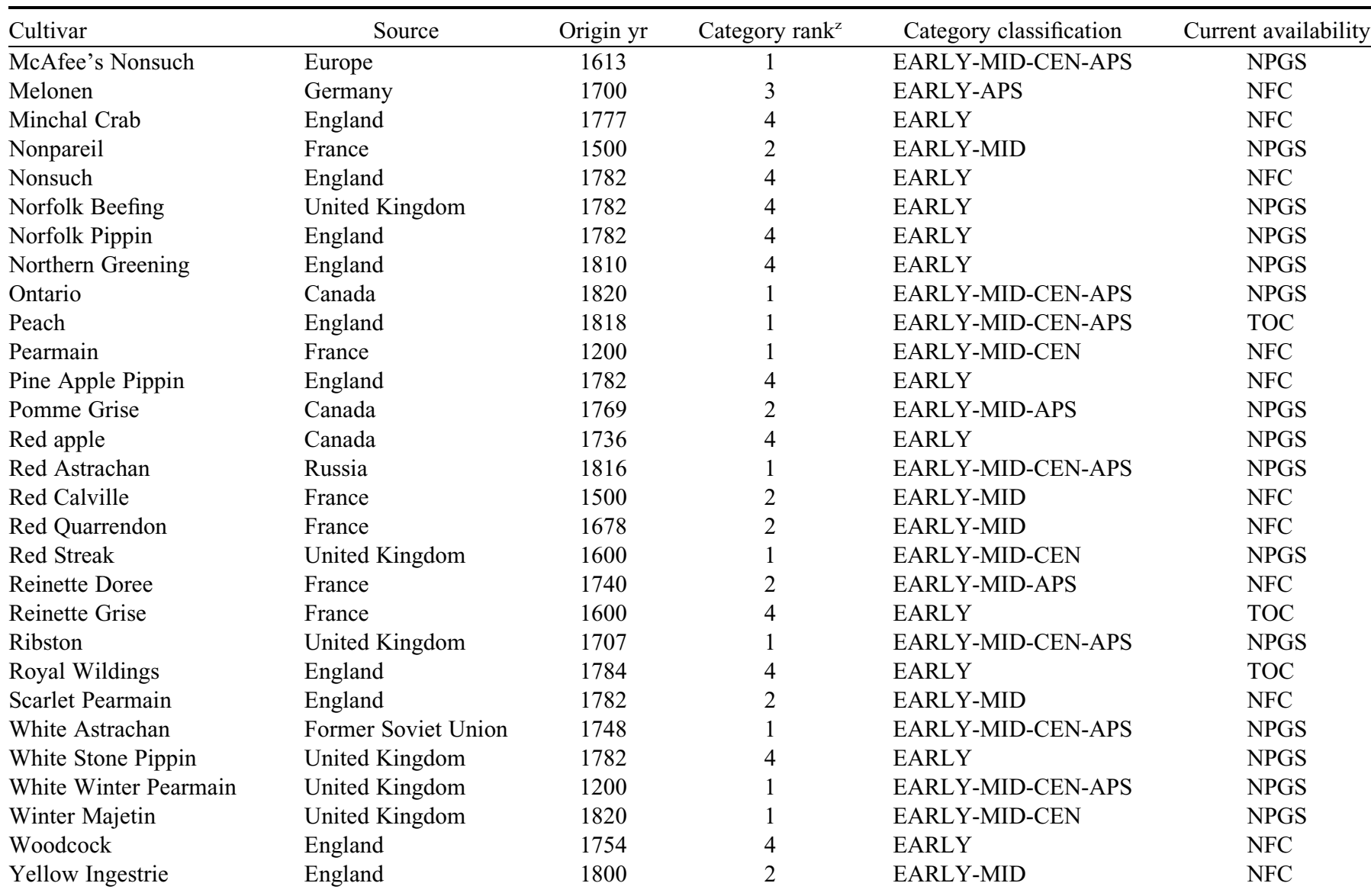

${ }^{\mathrm{z}}$ Category 1 apple cultivars were present in at least 10 of the 49 nursery catalogs dated between 1888 and 1907 or identified in at least three time periods in the literature (before 1830, between 1830 and 1869, and between 1870 and 1907). Category 2 cultivars were identified in the literature in at least two time periods (either before 1830 and between 1830 and 1869 , or between 1830 and 1869 and between 1870 and 1907). Category 3 cultivars were only found in the literature in one time period (before 1830, between 1830 and 1869, or between 1870 and 1907) and were also recommended by the American Pomological Society (APS). Category 4 cultivars were found only in the literature in one time period (before 1830, between 1830 and 1869, or between 1870 and 1907) but were not included in the APS recommendations. Category 4 cultivars were also those that were listed in the APS recommendations, but not documented in the literature.

A
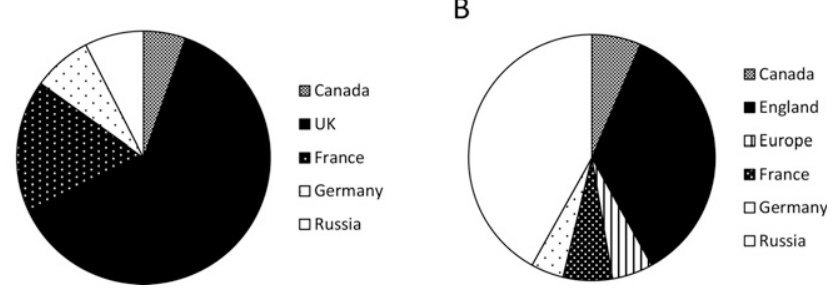

Fig. 4. Apple cultivars present in the United States that originated in other countries. (A) Countries from which at least $3 \%$ of the cultivars were imported before 1830. (B) Countries from which at least 3\% of the cultivars were imported between 1805 and 1905 (from Ragan, 1905). Year listings for 5A and $5 \mathrm{~B}$ overlap because data were derived from different sources.

important for preservation. Although we could not definitively remove all synonyms from our inventoried cultivars, we did identify and standardize cultivar names to removed etymological duplicates.

Availability of historic materials in the United States has been dependent on access to cultivars in the national collections of other countries (such as England), apple breeder collections, public and private collections, and from commercial nurseries. The data herein provide an update to the previously published report (Fowler and Mooney, 1990), and demonstrate that 90\% of the apple cultivars that were ranked as category 1 in the current study are available (Table 2), although NPGS fruit collection clonal germplasm repositories have only been in place since the 1980s [the first farm manager for the PGRU was hired in 1983 and the first curator for the apple collection was hired in 1984 (Postman et al., 2006)].

Since every apple seedling is unique, it is both impractical and impossible to conserve every apple genotype within genebank collections. Instead, a critical subset of the important variation is conserved. This subset is most likely a combination of landrace, historical, recent cultivars, key breeding lines and parents, mutants with desirable traits, and representative subsets of wild species. These genebank materials serve as genetic resources for cultivar comparisons, breeding, and research applications (Holland et al., 2006; Volk et al., 2015).

The importance of maintaining valuable cultivars in genebanks is underscored by the fact that commercially available apple cultivars have changed over time (Bonany et al., 2014; 


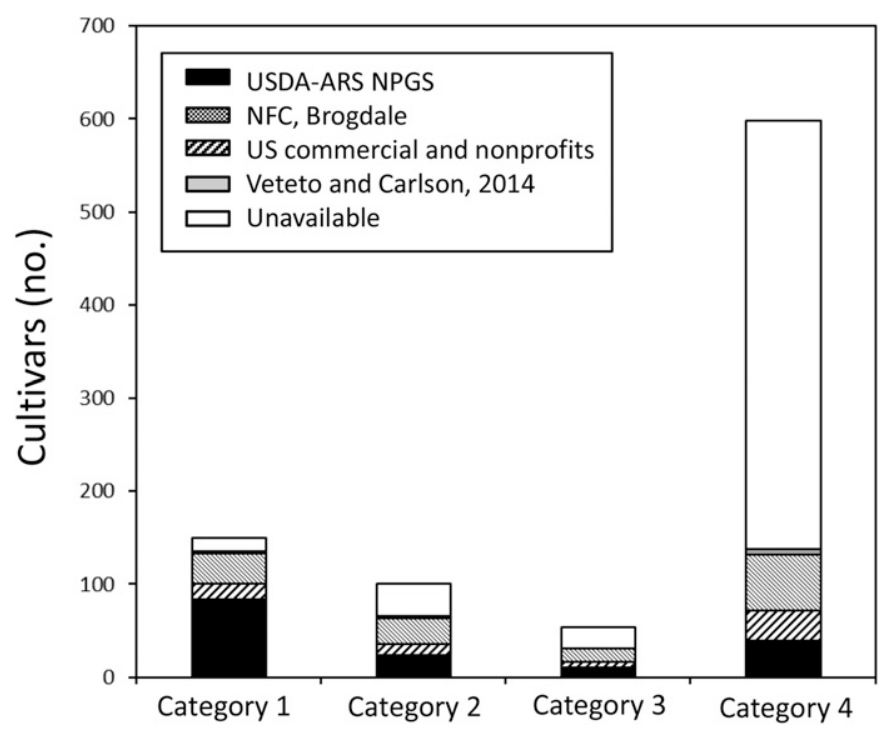

Fig. 5. Availability in 2015 of 891 historic apple cultivars. The sources were queried in the following order: U.S. Department of Agriculture, Agricultural Research Service National Plant Germplasm System, National Fruit Collection (Brodgale, UK), Temperate Orchard Conservancy (Molalla, OR), Greenmantle Nursery (Garberville, CA), Urban Homestead (Bristol, VA), Kuffel Creek Apple Tree Nursery (Riverside, CA), Albemarle CiderWorks (North Garden, VA), Salt Spring Apple Co. (Salt Spring Island, BC, Canada), and Veteto and Carlson (2014). If cultivars or synonyms were not available from any of these sources, they were considered unavailable. Category 1 apple cultivars were present in at least 10 of the 49 nursery catalogs dated between 1888 and 1907 or identified in at least three time periods in the literature (before 1830, between 1830 and 1869, and between 1870 and 1907). Category 2 cultivars were identified in the literature in at least two time periods (either before 1830 and between 1830 and 1869 , or between 1830 and 1869 and between 1870 and 1907), Category 3 cultivars were only found in the literature in one time period (before 1830, between 1830 and 1869, or between 1870 and 1907) and were also recommended by the American Pomological Society [APS (Ragan, 1909)]. Category 4 cultivars were found only in the literature in one time period (before 1830, between 1830 and 1869 , or between 1870 and 1907) but were not included in the APS recommendations. Category 4 cultivars were also those that were listed in the APS recommendations, but not documented in the literature.

Dolan, 2009; Yue and Tong, 2011). Previous work demonstrated that there were no significant changes in the genetic diversity of $M$. $\times$ domestica across the last 8 centuries; however, there is a lower level of diversity represented by the cultivars that are currently produced commercially (Gross et al., 2014; Noiton and Alspach, 1996). Dolan (2009) counted the number of apple cultivars available in Stark Brothers Nursery (Louisiana, MO) catalogs between 1918 and 1935. Dolan (2009) found that 95 cultivars were available in 1918, 33 cultivars were available in 1928, and 19 cultivars were available in 1935 . Dolan (2009) also identified a significant shift in the most popular cultivars between 1910 and 1942. The most popular apple cultivars in 1910 were Baldwin, Ben Davis, Jonathan, Northern Spy, Rhode Island Greening, Roxbury Russett, Winesap, King of Tompkin's County, Newtown Pippin, and York Imperial (Dolan, 2009). By 1942, the most popular apple cultivars were Red Delicious, Jonathan, McIntosh, Rome Beauty, York Imperial, Stayman Winesap, Northern Spy, Rhode Island Greening, Newtown Pippin, and Grimes Golden (Dolan, 2009). The 1910 list of cultivars included all cultivars identified in this work. It is notable that in our references, 'Red Delicious', also known as 'Hawkeye', was only cited twice. By 1942, 'Red Delicious' had grown to be the most popular apple cultivar and it is still grown on the most acreage in the United States today (Volk et al., 2015).

Apple trees that are genetically identical to the original named cultivars have been maintained for centuries because apples are clonally propagated (Juniper and Mabberley, 2006). For example, Herefordshire Pearmain and White Winter Pearmain are apple cultivars that were first documented as early as $1200 \mathrm{CE}$ and are still available (Smith, 1971). Because apple trees can live for more than 100 years, original historic cultivars remain in fields, but many of those trees are dying (Routson et al., 2009). In 2014, Veteto and Carlson wrote a survey of 633 distinct ethnotaxa of heirloom apples (synonyms not removed) identified in southern Appalachia. Their report documented the existence of 328 orchards in North Carolina in 1976, which had declined to 117 orchards in 2006. In this region, consumer demand for modern cultivars is resulting in the phasing out of many historic cultivars (Veteto and Carlson, 2014). We compared our list of unavailable materials to the inventory presented by Veteto and Carlson (2014) and found 10 historic cultivars that might still be available in Appalachian orchards (Fall Orange, Greening, Hall's Red, Haskell's Sweet, Hogshead, Honey, Spencer's Pippin, Summer Limbertwig, Delaware Red Winter, and Red Winter).

There is an interest in determining the identity of historic fruit trees in private collections and on public lands. Historic cultivars in the NPGS collection provide a standard reference for DNA fingerprinting efforts (Bassil et al., 2008; Routson et al., 2009). This reference set of information would be strengthened by the inclusion of samples of important historic cultivars that are not currently available in NPGS. The existence of a DNA fingerprinting database aids in cultivar identification and also serves as collection management tool in the identification of duplicates or possibly mislabeled collection materials (Gross et al., 2012).

As consumers, in the form of hobbyists and horticultural plant collectors as well as niche market producers, embrace the concept of consuming fruit cultivars that are genetically identical to those that were consumed decades or centuries ago, historic apple cultivars become valued and appreciated (Burford, 2013; Hatch, 1998). It is likely that a network of national and international apple collections, as well as nonprofit organizations and commercial nurseries, will ensure that historical apple cultivars are available for centuries to come.

\begin{abstract}
"I fear that he who walks over these fields a century hence will not know the pleasure of knocking off wild apples. Ah, poor man, there are many pleasures which he will not know!" (Thoreau, 1913)
\end{abstract}

\section{Literature Cited}

Bassil, N., J. Postman, K. Hummer, S. Dolan, and L. Lawliss. 2008. Molecular fingerprints identify historic pear trees in two U.S. national parks. Acta Hort. 800:417-422.

Bellon, M.R. and S.B. Brush. 1994. Keepers of maize in Chiapas, Mexico. Econ. Bot. 48:196-209.

Bonany, J., C. Brugger, A. Buehler, J. Carbó, S. Codarin, F. Donati, G. Echeverria, S. Egger, W. Guerra, C. Hilaire, I. Höller, I. Iglesias, K. Jesionkowska, D. Konopacka, D. Kruczyńska, A. Martinelli, C. Petiot, S. Sansavini, R. Stehr, and F. Schoorl. 2014. Preference mapping of apple varieties in Europe. Food Qual. Prefer. 32:317329.

Börjeson, A. 2015. Sorter av köksväxter. Svenska priskuranter frå1800-talet till 1930. 17 Feb. 2016. <http://www.nordgen.org/ index.php/en/content/view/full/62/>. 
Burford, T. 2013. Apples of North America: 192 exceptional varieties for gardeners, growers, and cooks. Timber Press, Portland, OR.

Calhoun, C.L. 2010. Old southern apples. Chelsea Green Publ., White River Junction, VT.

Chappell, G.W. 2000. Southern plant lists. 22 Feb. 2016. <http:// southerngardenhistory.org/wp-content/uploads/2015/12/ SouthernPlantLists.pdf $>$.

Diamond, D.H. 2010. Origins of pioneer apple orchards in the American west: Random seeding versus artisan horticulture. Art Hist. 84:423-450.

Dolan, S.A. 2009. Fruitful legacy: A historic context of orchards in the United States, with technical information for registering orchards in the National Register of Historic Places. Natl. Park Serv., U.S. Govt. Printing Office, Washington, D.C.

Ellis, W. 1754. Compleat cyderman, or, the present practice of raising plantations of the best cyder apple and perry pear-trees. R. Baldwin, London, UK.

Fowler, C. and P. Mooney. 1990. Shattering. Food, politics, and the loss of genetic diversity. Univ. Arizona Press, Tucson, AZ.

Gibb, C. 1884. On the Russian apples imported by U.S. Department of Agriculture in 1870. Gazette Printing Co., Montreal, QC, Canada.

Goland, C. and S. Bauer. 2004. When the apple falls close to the tree: Local food systems and the preservation of diversity. Renew. Agr. Food Syst. 19:228-236.

Grassbaugh, E.M., E.E. Regnier, and M.A. Bennett. 2004. Comparison of organic and inorganic mulches for heirloom tomato production. Acta Hort. 638:171-176.

Gross, B.L., A.D. Henk, C.M. Richards, G. Fazio, and G.M. Volk. 2014. Genetic diversity in Malus $\times$ domestica (Rosaceae) through time in response to domestication. Amer. J. Bot. 101:1770-1779.

Gross, B., G.M. Volk, C.M. Richards, P. Forsline, G. Fazio, and C.-T. Chao. 2012. Identification of "duplicate" accessions within the USDA-ARS National Plant Germplasm System Malus collection. J. Amer. Soc. Hort. Sci. 137:333-342.

Hansen, A.L. 2010. The organic farming manual. Storey Publ., North Adams, MA.

Harker, F.R., F.A. Gunson, and S.R. Jaeger. 2003. The case for fruit quality: An interpretive review of consumer attitudes, and preferences for apples. Postharvest Biol. Technol. 28:333-347.

Hatch, P.J. 1998. The fruits and fruit trees of Monticello. Univ. Virginia Press, Charlottesville, VA.

Heald, P.J. and S. Chapman. 2016. Crop diversity report card for the twentieth century: Diversity bust or diversity boom? 21 Feb. 2016. $<$ http://papers.ssrn.com/sol3/papers.cfm?abstract_id=1462917>.

Hokanson, S.C., J.R. McFerson, P.L. Forsline, W.F. Lamboy, J.J. Luby, A.D. Djangaliev, and H.S. Aldwinckle. 1997. Collecting and managing wild Malus germplasm in its center of diversity. HortScience 32:173-176.

Holland, D., I. Bar-Yaakov, T. Trainin, and K. Hatib. 2006. Old deciduous fruit trees of the Rosaceae in Israel and their utilization in modern agriculture and breeding. Isr. J. Plant Sci. 54:167-177.

Jarvis, D.I., A.H.D. Brown, P.H. Cuong, L. Collado-Panduro, L. Latournerie-Moreno, S. Gyawali, T. Tanto, M. Sawadogo, I. Mar, M. Sadiki, N.T. Hue, L. Arias-Reyes, D. Balma, J. Bajracharya, F. Castillo, D. Rijal, L. Belqadi, R. Rana, S. Saidi, J. Ouedraogo, R. Zangre, K. Rhrib, J.L. Chavez, D. Schoen, B. Sthapit, P. De Santis, C. Fadda, and T. Hodgkin. 2008. A global perspective of the richness and evenness of traditional crop-variety diversity maintained by farming communities. Proc. Natl. Acad. Sci. USA 105:5326-5331.

Juniper, B.E. and D.J. Mabberley. 2006. The story of the apple. Timber Press, Portland, OR.

Kenrick, W. 1835. The new American orchardist. Russell Odiorne Metcalf, Boston, MA.

Kenrick, W. 1848. An account of the most valuable varieties of fruit. Otis Broaders, Boston, MA.

Mack, R.N. 1991. The commercial seed trade: An early disperser of weeds in the United States. Econ. Bot. 45:257-273.
Merwin, I. 2008. Some antique apples for modern orchards. New York Fruit Qrtly. 16(winter):11-17.

Morgan, J. and A. Richards. 1993. The book of apples. Ebury Press, London, UK.

National Fruit Collection (NFC). 2015. National Fruit Collection search. 7 June 2015. <www.nationalfruitcollection.org.uk/search. php $>$.

Noiton, D.A.M. and P.A. Alspach. 1996. Founding clones, inbreeding, coancestry, and status number of modern apple cultivars. J. Amer. Soc. Hort. Sci. 122:773:782.

Pincetl, S., S.S. Prabhu, T.W. Gillespie, G.D. Jenerette, and D.E. Pataki. 2013. The evolution of tree nursery offerings in Los Angeles County over the last 110 years. Landsc. Urban Plan. 118:10-17.

Postman, J., K. Hummer, E. Stover, R. Krueger, P. Forsline, L.J. Grauke, F. Zee, T. Ayala-Silva, and B. Irish. 2006. Fruit and nut genebanks in the U.S. National Plant Germplasm System. HortScience 41:1188-1194.

Quiros, C.F., S.B. Brush, D.S. Douches, K.S. Zimmerer, and G. Huestis. 1990. Biochemical and folk assessment of variability of Andean cultivated potatoes. Econ. Bot. 44:254-266.

Ragan, W.H. 1905. Nomenclature of the apple: A catalogue of the known varieties referred to in American publications from 1804 to 1904. USDA-BPI Bul. No. 56.

Ragan, W.H. 1909. Fruits recommended by the American Pomological Society for cultivation in the various sections of the United States and Canada. USDA-BPI Bul. No. 151.

Routson, K.J., A.A. Reilley, A.D. Henk, and G.M. Volk. 2009. Identification of historic apple trees in the southwestern United States and implications for conservation. HortScience 44:589594.

Sadiki, M., D.I. Jarvis, D. Rijal, J. Bajracharya, N.N. Hue, T.C. Camacho-Villa, L.A. Burgos-May, M. Sawadogo, D. Balma, D. Lope, L. Arias, I. Mar, D. Karamura, D. Williams, J. L. ChavezServia, B. Sthapit, and V.R. Rao. 2007. Variety names, p. 34-76. In: D. Jarvis (ed.). Managing biodiversity in agricultural ecosystems. Columbia Univ. Press, New York, NY.

Smith, M.W.G. 1971. National apple register of the United Kingdom. London Ministry of Agr. Fisheries Food (2002 reprint by Castlepoint Press, Colvend, UK).

Solberg, S.Ø. and L. Breian. 2015. Commercial cultivars and farmers' access to crop diversity: A case study from the Nordic region. Agr. Food Sci. 24:150-163.

Temperate Orchard Conservancy. 2016. Apple varieties from the Nick Botner Collection and other generous sources. 22 Feb. 2016. <http:// www.temperateorchardconservancy.org/BotnerAppleCollection. pdf>.

Thoreau, H.D. 1913. Excursions. Thomas Y. Crowell, New York, NY. Turner, N.J. and R.J. Hebda. 1990. Contemporary use of bark for medicine by two Salishan native elders of southeast Vancouver Island, Can. J. Ethnopharmacol. 29:59-72.

Turner, N.J. and K.L. Turner. 2008. "Where our women used to get the food": Cumulative effects and loss of enthobotanical knowledge and practice; case study from coastal British Columbia. Botany 86:103115.

U.S. Department of Agriculture (USDA). 2015. Germplasm Resources Information Network (GRIN). 7 June 2015. <http://www.ars-grin. gov/cgi-bin/npgs/html/crop.pl?115>.

van de Wouw, M., R. van Treuren, and T. van Hintum. 2011. Authenticity of old cultivars in genebank collections: A case study on lettuce. Crop Sci. 51:736-746.

van Treuren, R., J.M.M. Engels, R. Hoekstra, and T.J.L. van Hintum. 2009. Optimization of the composition of crop collections for ex situ conservation. Plant Genet. Resour.: Characterization Util. 7:185-193.

van Treuren, R., H. Kemp, G. Ernsting, B. Jongejans, H. Houtman, and L. Visser. 2010. Microsatellite genotyping of apple (Malus $\times$ domestica Borkh.) genetic resources in the Netherlands: Application in collection 
management and variety identification. Genet. Resources Crop Evol. $57: 853-865$.

Veteto, J.R. and S.B. Carlson. 2014. Climate change and apple diversity: Local perceptions from Appalachian North Carolina. J. Ethnobiol. 34:359-382.

Volk, G.M., C.T. Chao, J.L. Norelli, S. Brown, G. Fazio, C. Peace, J. McFerson, G.-Y. Zhong, and P. Bretting. 2015. The vulnerability of U.S. apple (Malus) genetic resources. Genet. Resources Crop Evol. 62:765-794.

Walters, C., G.M. Volk, and C.M. Richards. 2008. Genebanks in the post-genomic age: Emerging roles and anticipated uses. Biodiversity 9:68-71.

Warder, J.A. 1867. American pomology. Lovejoy and Son, New York, NY.
Yanovsky, E. 1936. Food plants of the North American Indians. U.S. Dept. Agr., Washington, D.C.

Yue, C., R.K. Gallardo, J. Luby, A. Rihn, J.R. McFerson, V. McCracken, D. Bedford, S. Brown, K. Evans, C. Weebadde, A. Sebolt, and A.F. Iezzoni. 2013. An investigation of U.S. apple producers' trait prioritization-evidence from audience surveys. HortScience 48:1378-1384.

Yue, C. and C. Tong. 2011. Consumer preferences and willingness to pay for existing and new apple varieties: Evidence from apple tasting choice experiments. HortTechnology 21:376-383.

Zeven, A.C. and W.A. Brandenburg. 1986. Use of paintings from the 16th to 19th centuries to study the history of domesticated plants. Econ. Bot. 40:397-408. 
Supplemental Table 1. References from which apple cultivar names were retrieved.

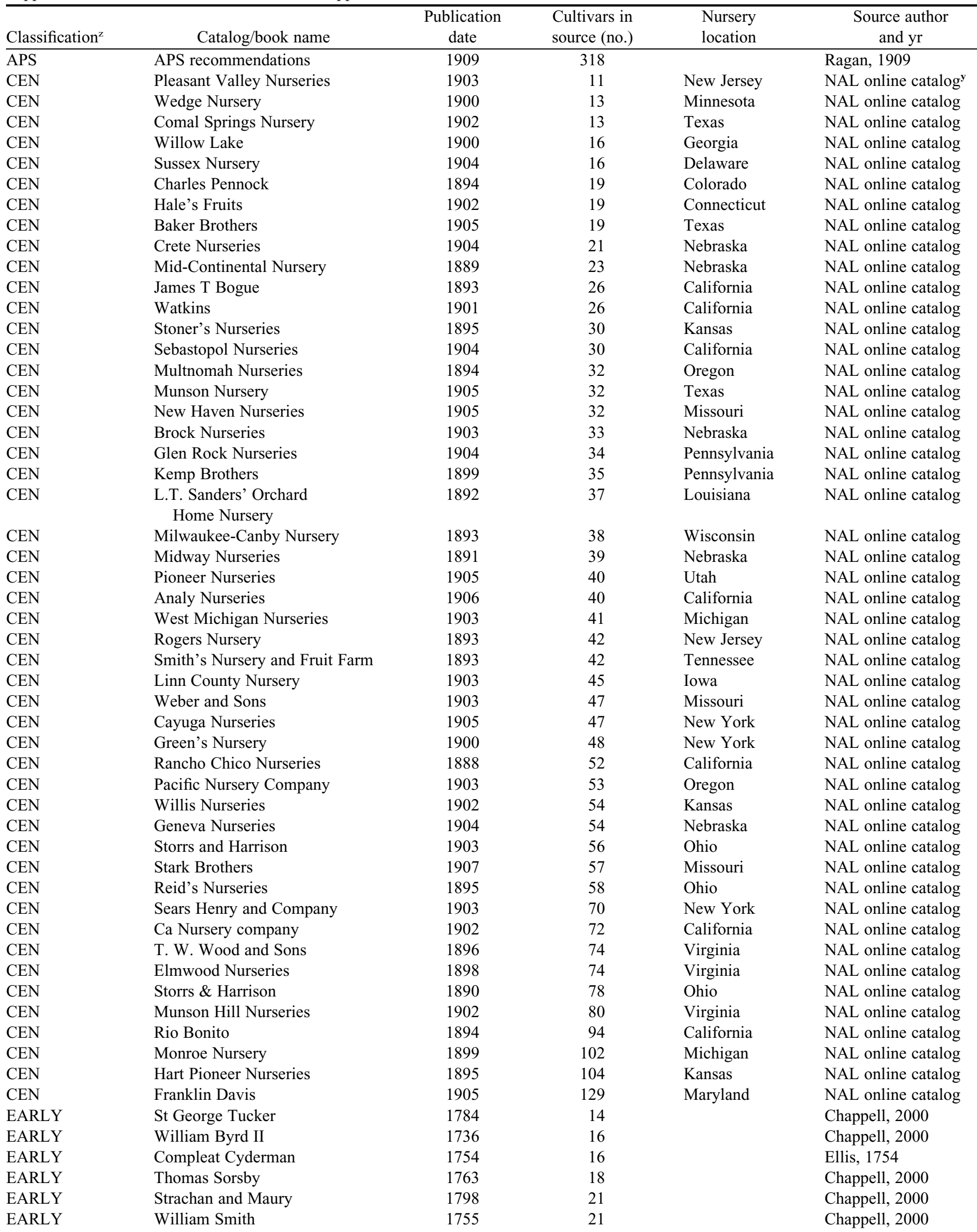


Supplemental Table 1. Continued.

\begin{tabular}{|c|c|c|c|c|c|}
\hline Classification $^{z}$ & Catalog/book name & $\begin{array}{l}\text { Publication } \\
\text { date }\end{array}$ & $\begin{array}{l}\text { Cultivars in } \\
\text { source (no.) }\end{array}$ & $\begin{array}{l}\text { Nursery } \\
\text { location }\end{array}$ & $\begin{array}{c}\text { Source author } \\
\text { and yr }\end{array}$ \\
\hline$\overline{\text { EARLY }}$ & Samuel Bailey & 1804 & 23 & & Chappell, 2000 \\
\hline EARLY & Monticello & Various & 53 & & Hatch, 1998 \\
\hline EARLY & William Pinkerton & 1782 & 102 & & Online catalog, NAL \\
\hline MID & Grown by Jacob Smith & 1844 & 11 & & Chappell, 2000 \\
\hline MID & New American Orchardist & 1835 & 116 & & Kenrick, 1835 \\
\hline \multirow[t]{3}{*}{ MID } & Vineland Nursery & 1858 & 122 & & Chappell, 2000 \\
\hline & The Book of Apples & Various & 14 & & $\begin{array}{l}\text { Morgan and Richards, } \\
1993\end{array}$ \\
\hline & American Pomology Apples & Various & 417 & & Warder, 1867 \\
\hline
\end{tabular}

${ }^{\mathrm{z}} \mathrm{APS}=$ American Pomological Society; EARLY = before 1830; MID = 1830-69; CEN = 1870-1907.

${ }^{\mathrm{y}} \mathrm{NAL}=$ National Agricultural Library, Beltsville, MD. 


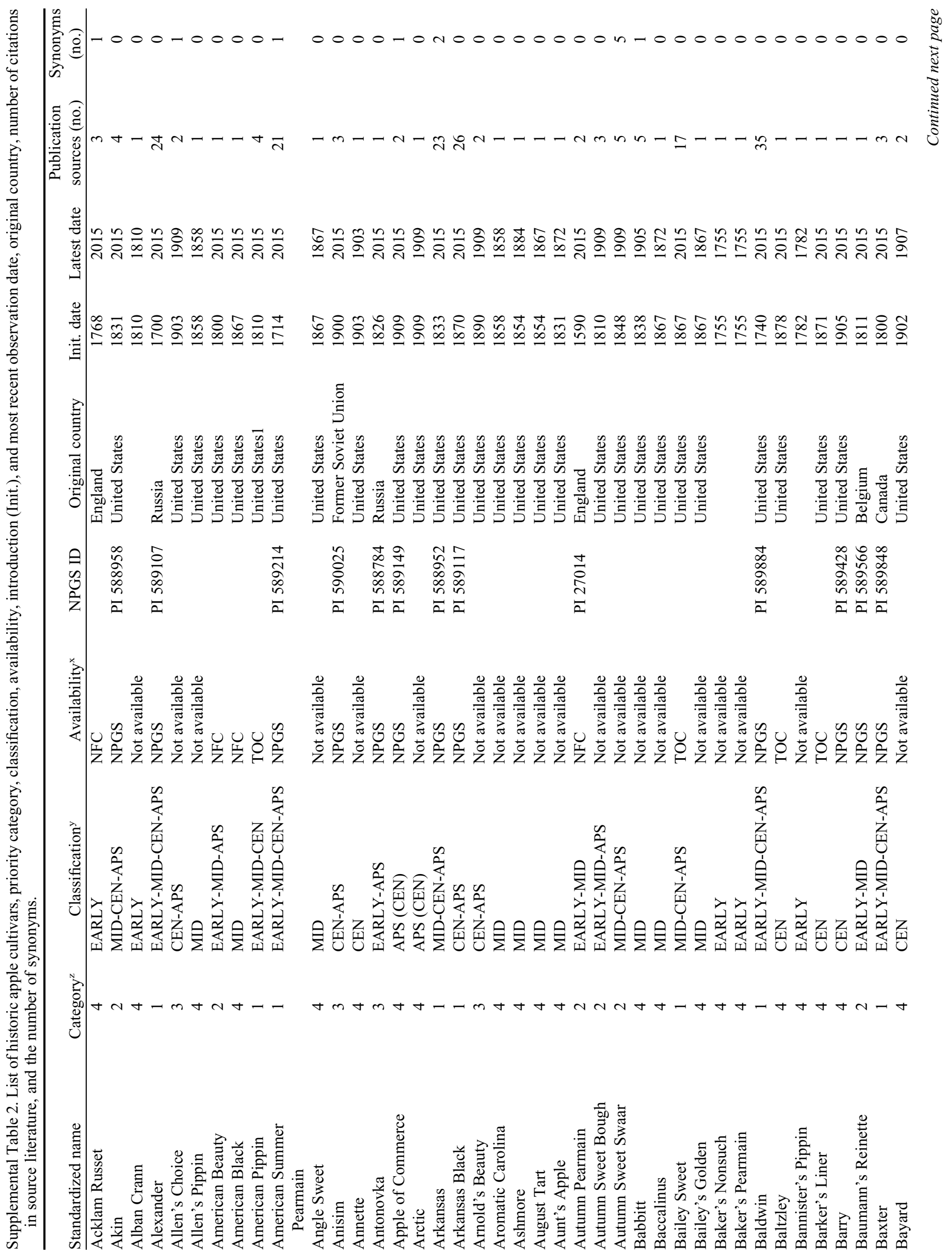




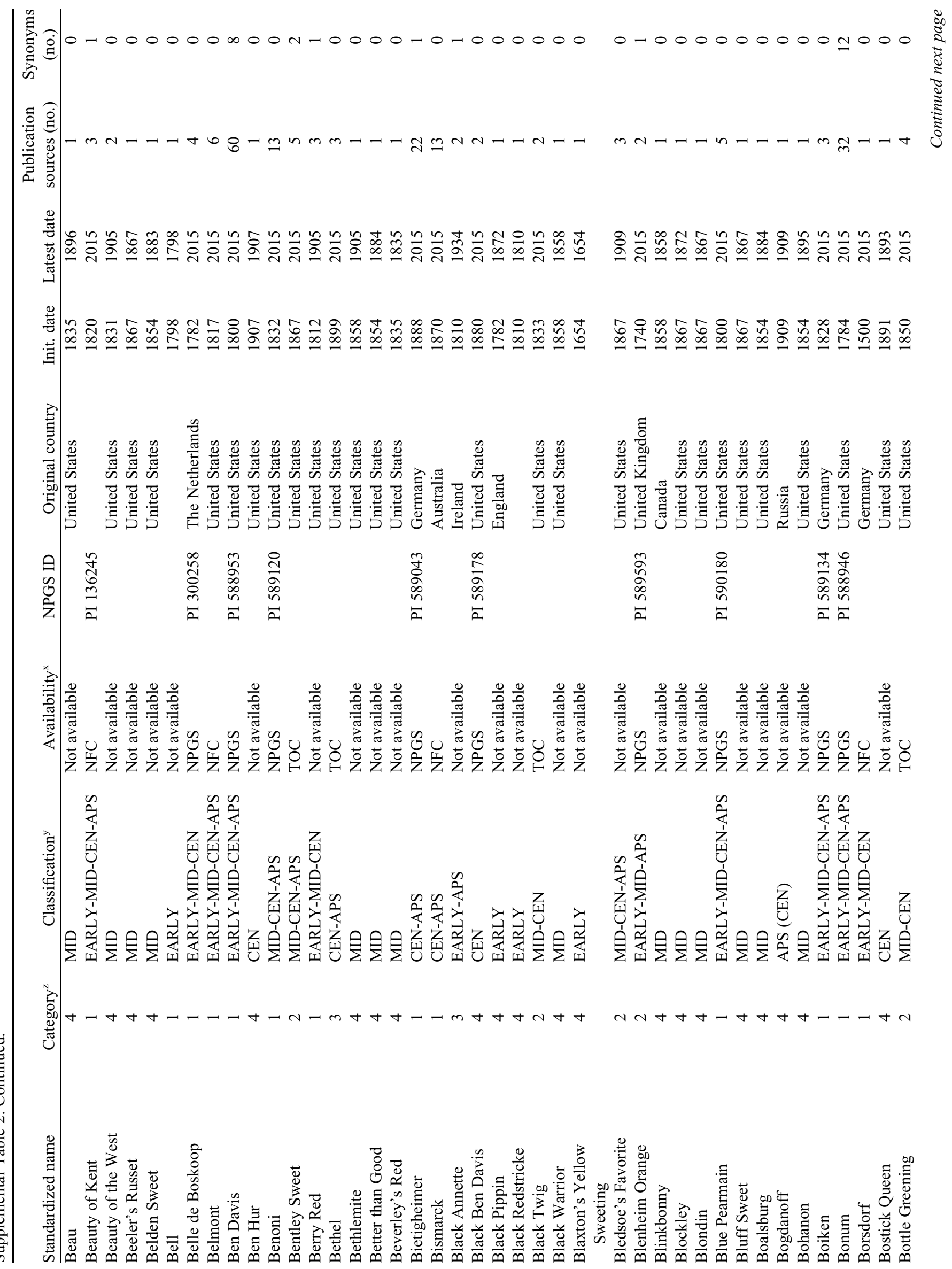




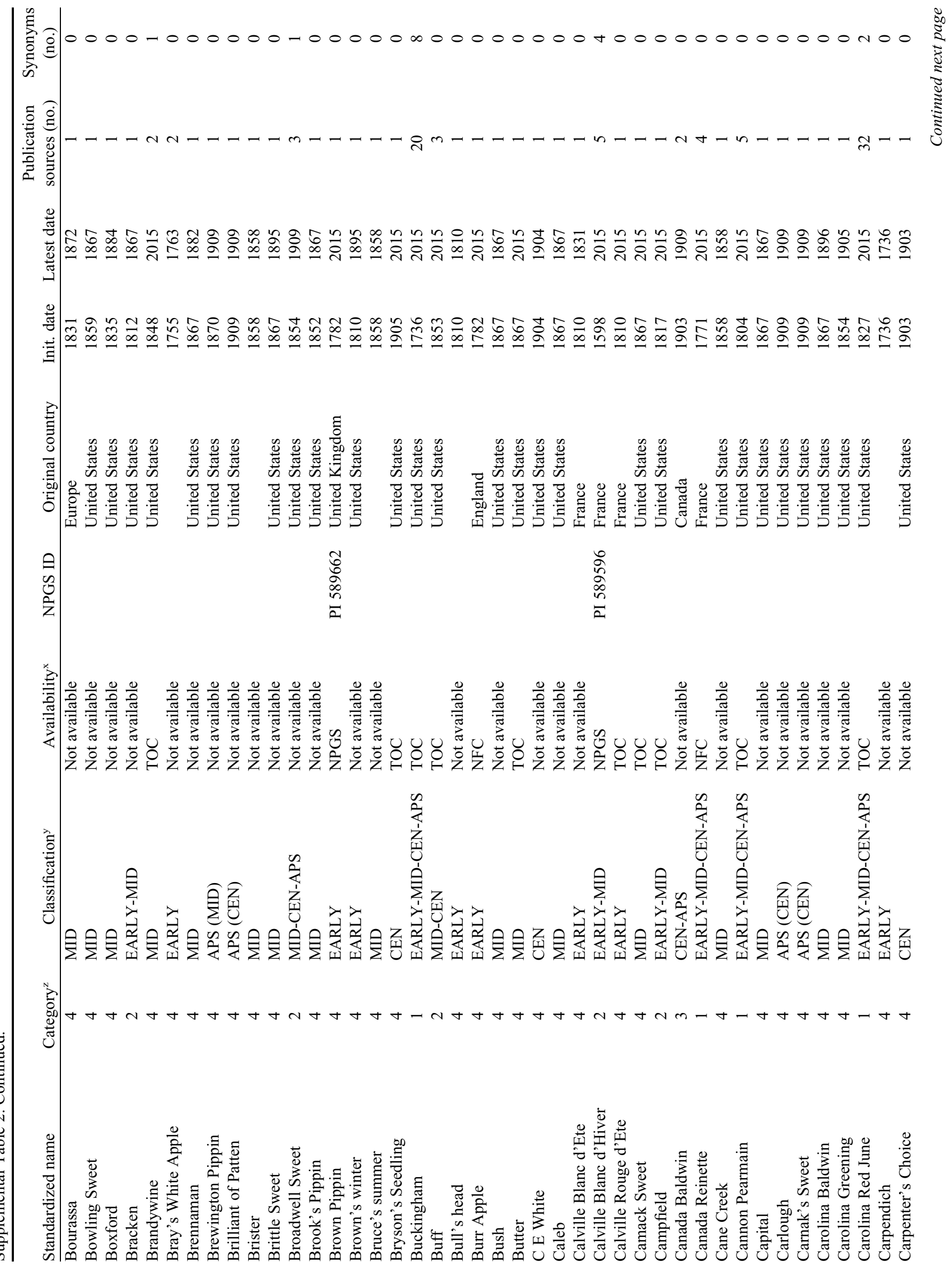




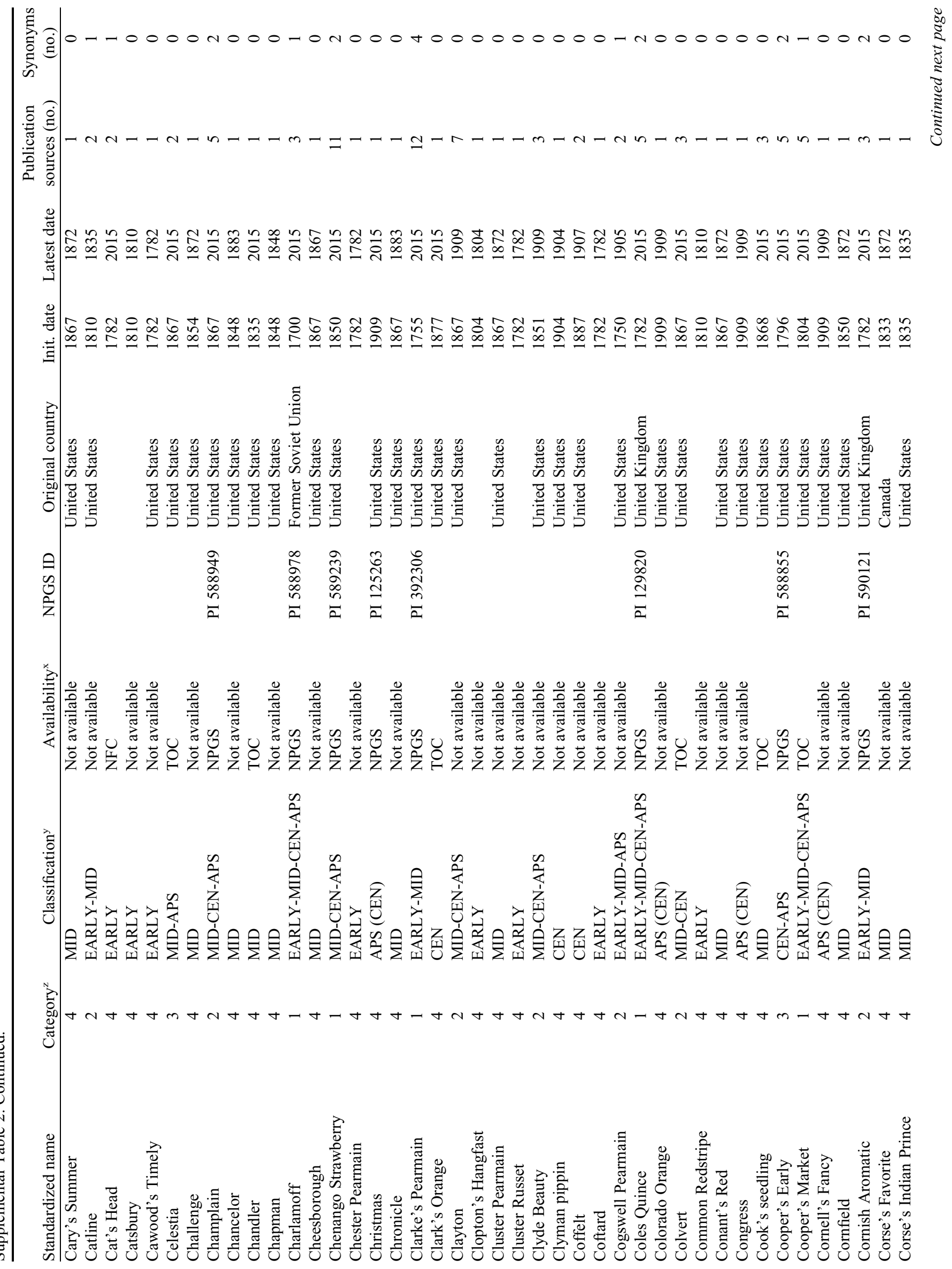




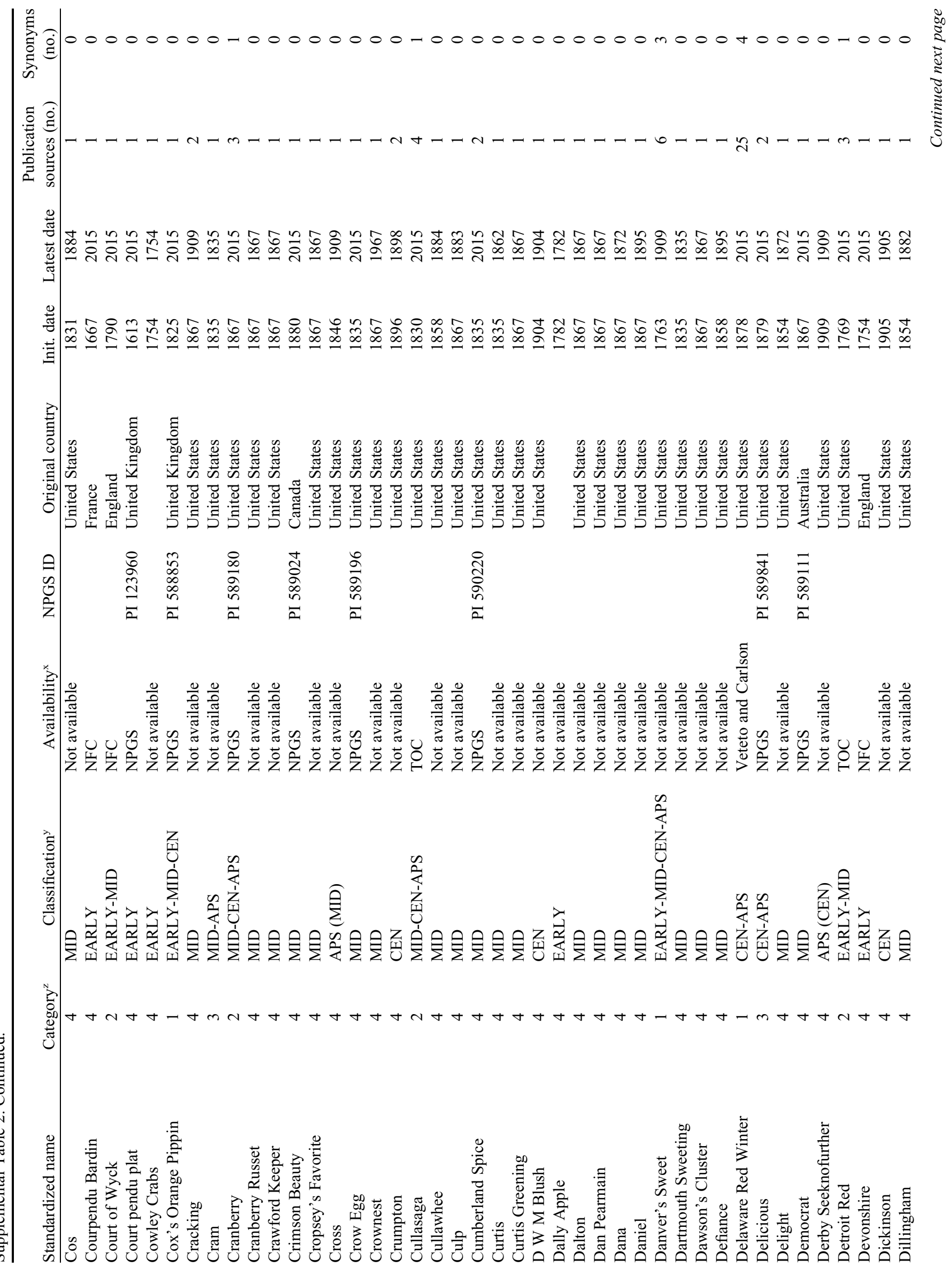




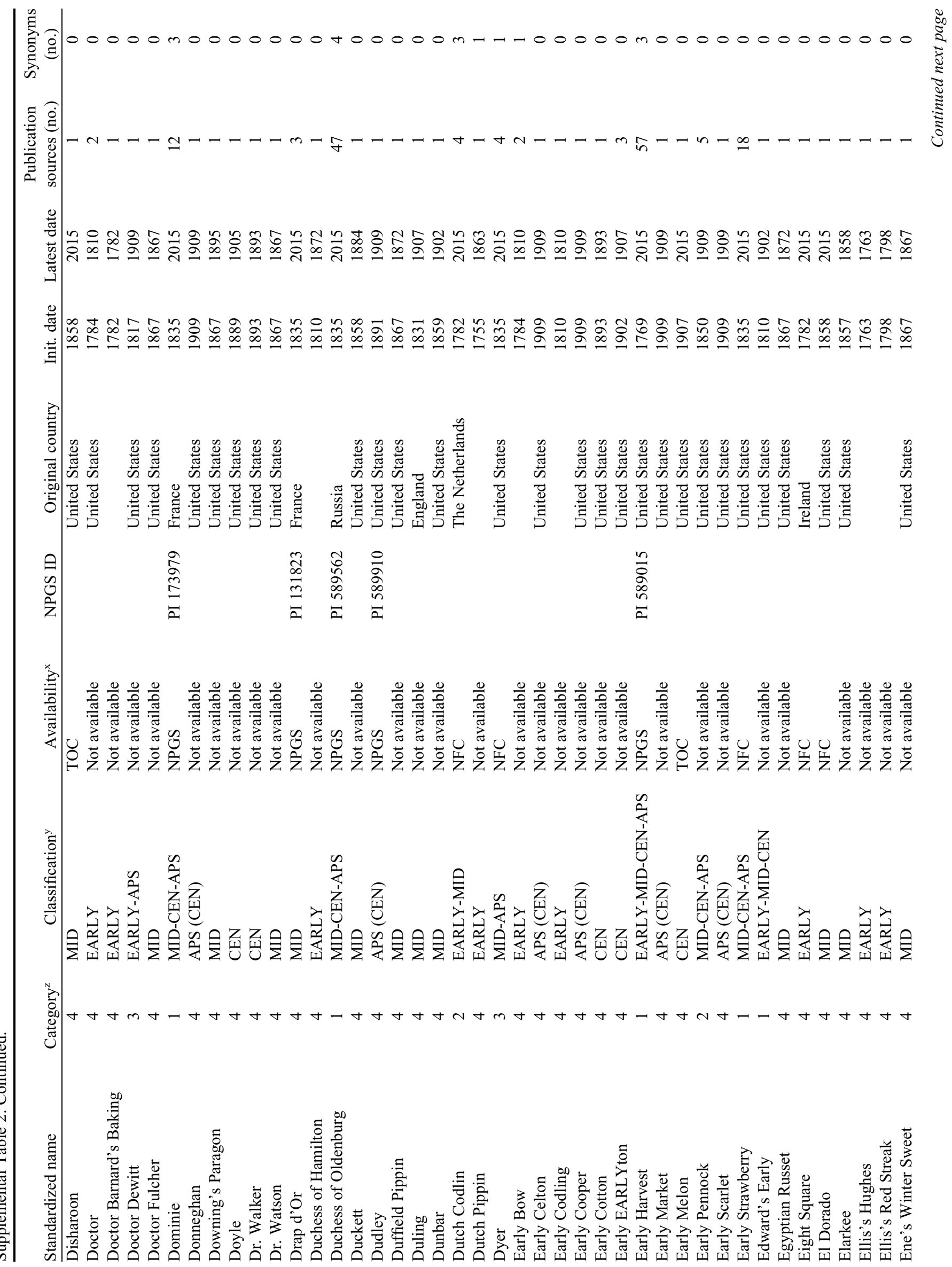




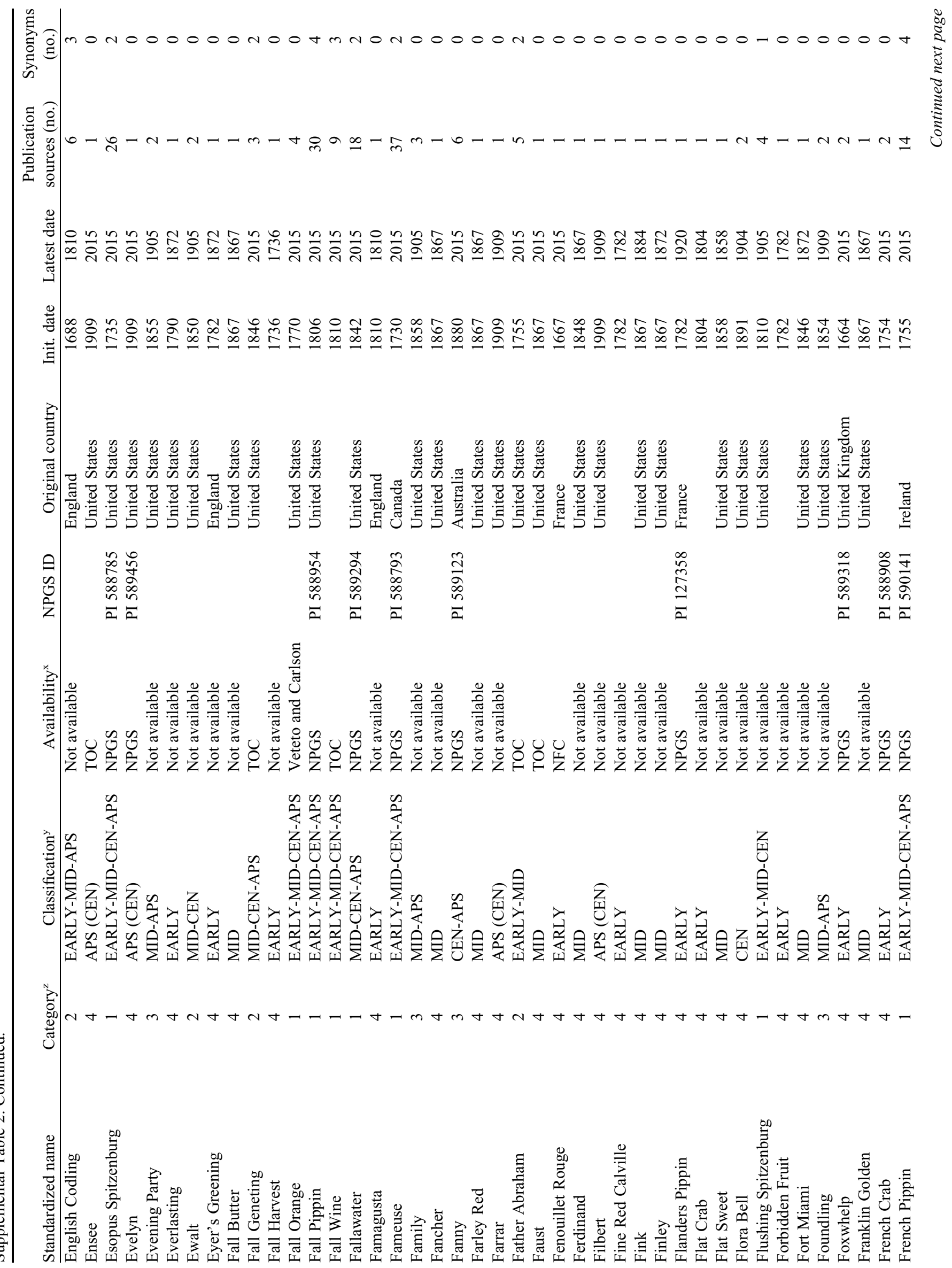




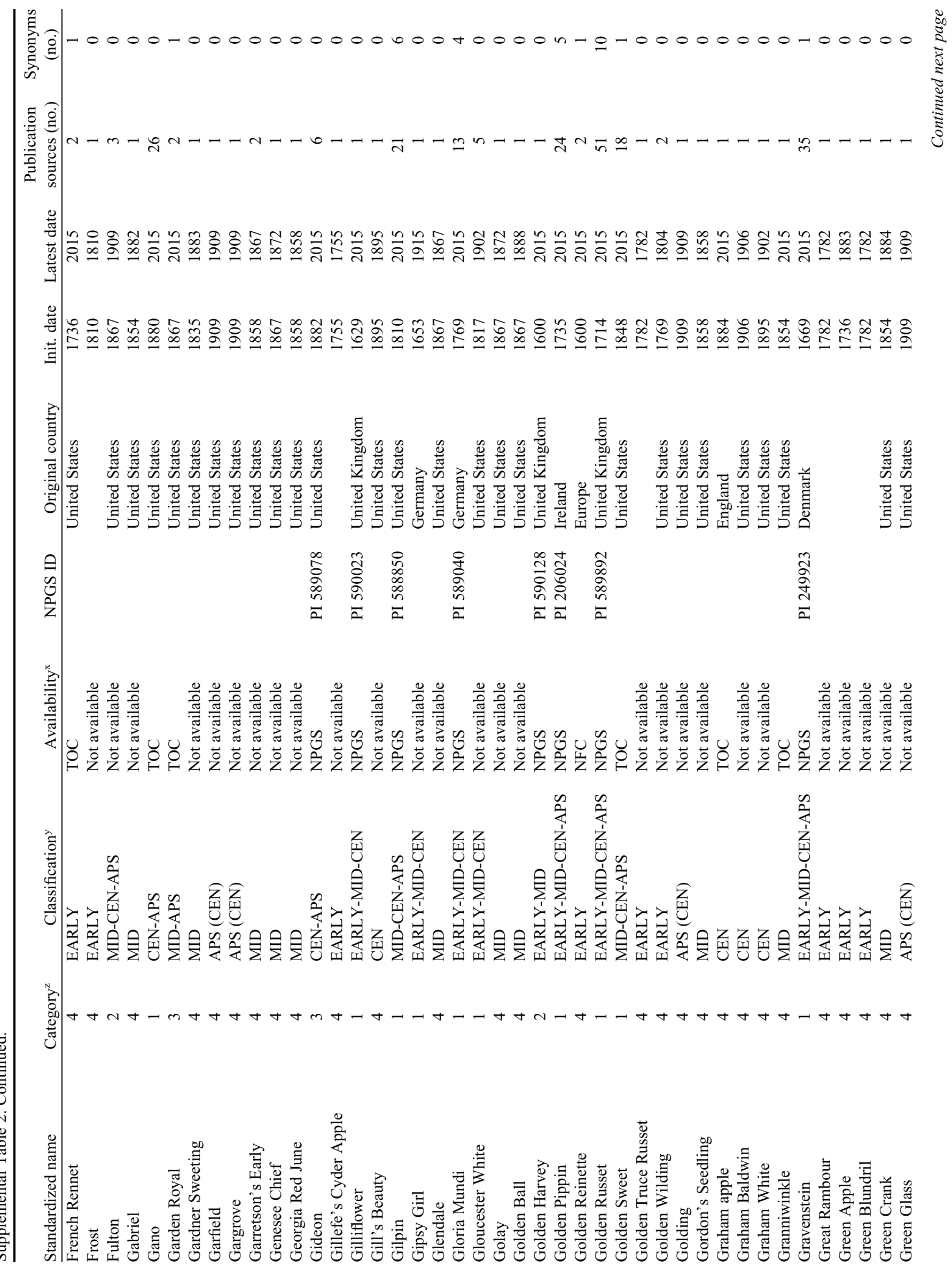




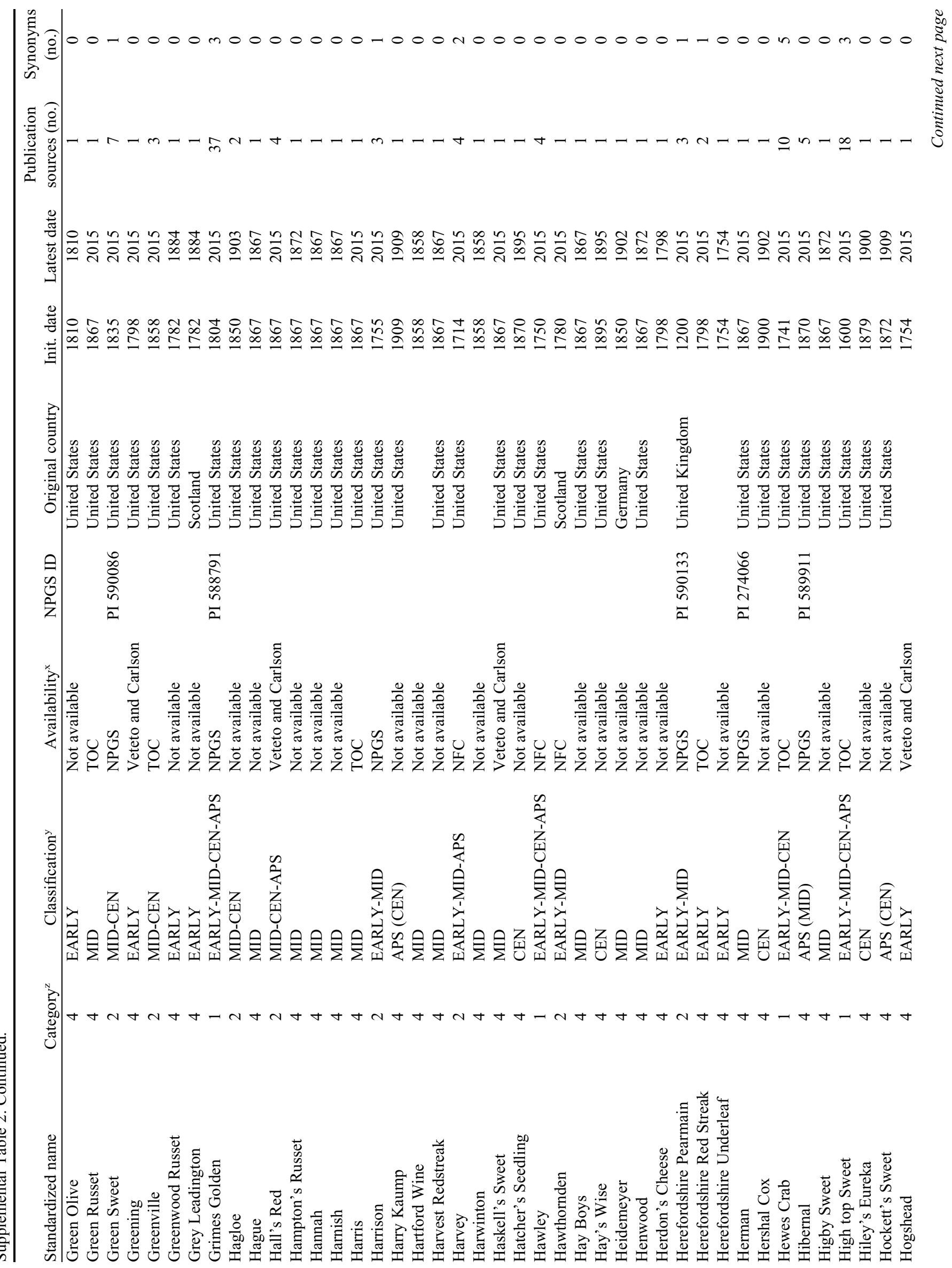




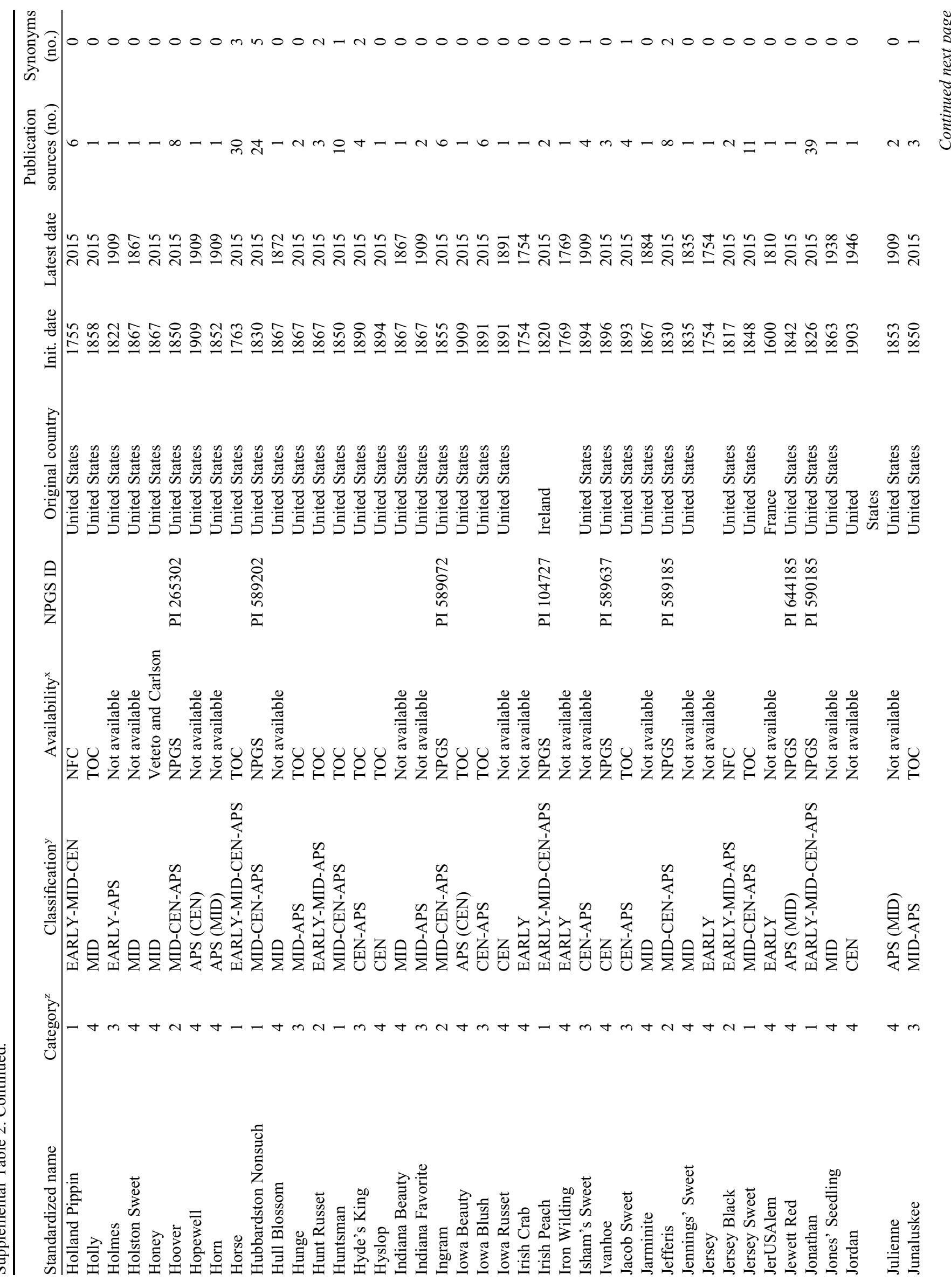




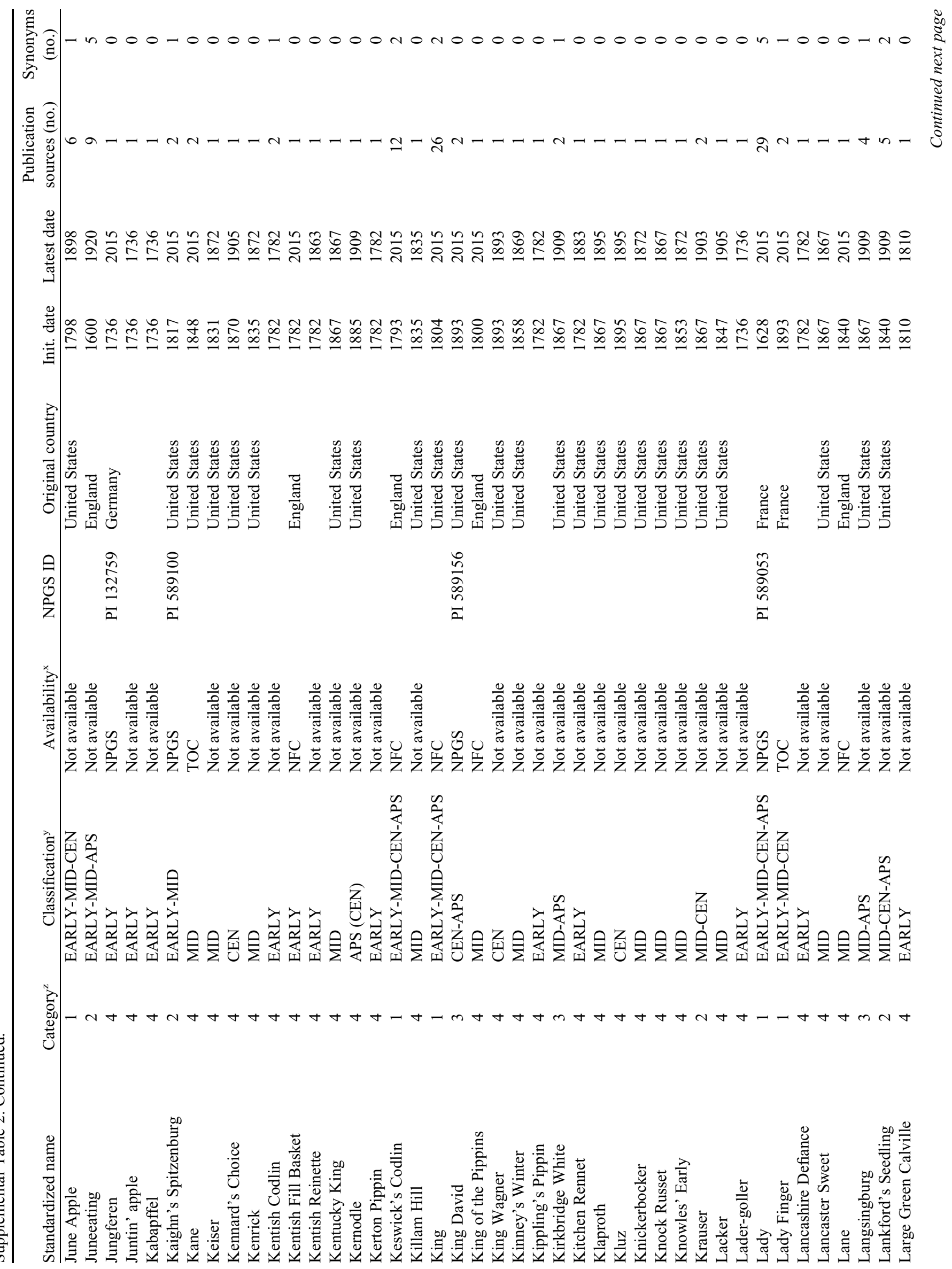




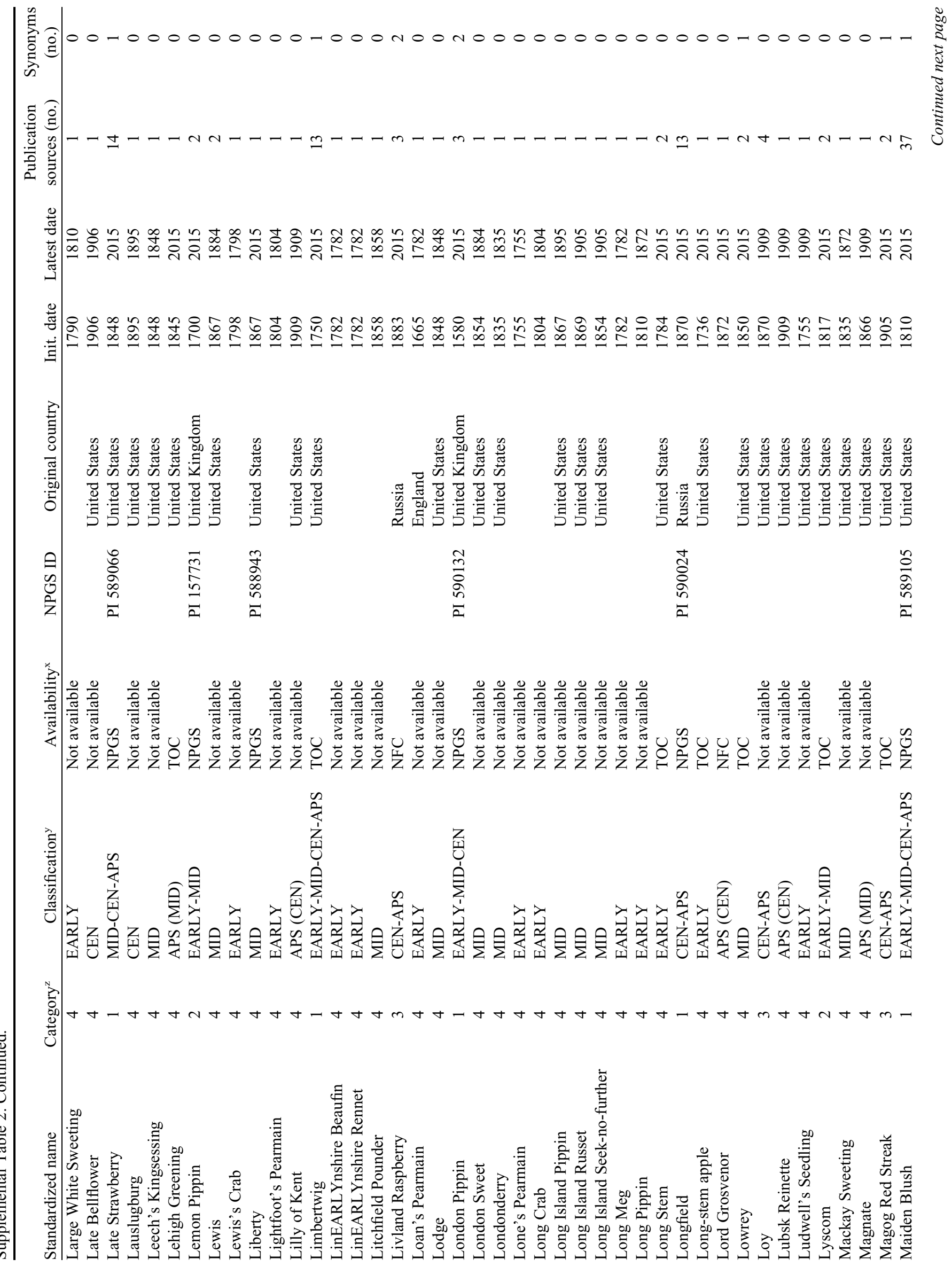




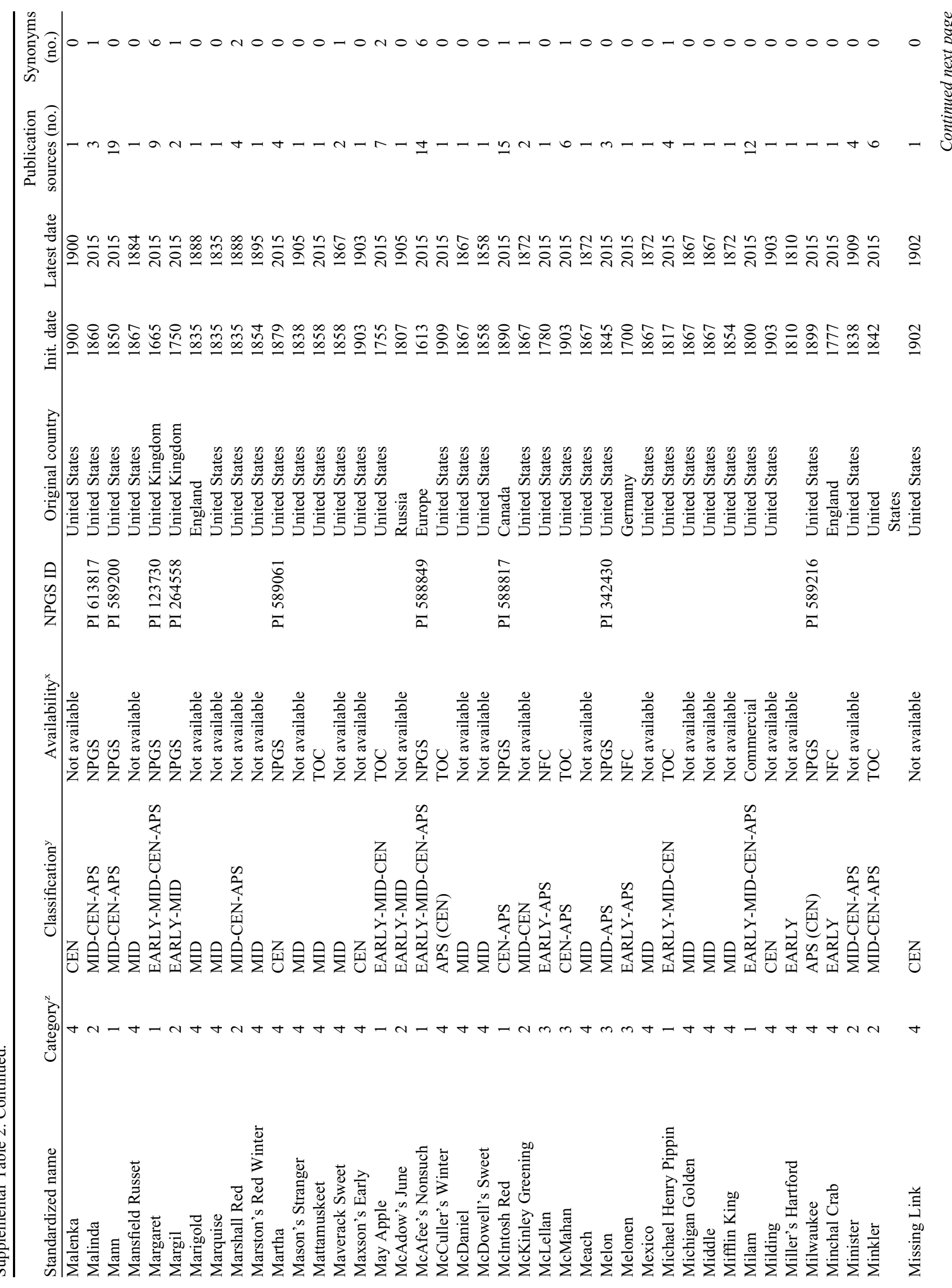




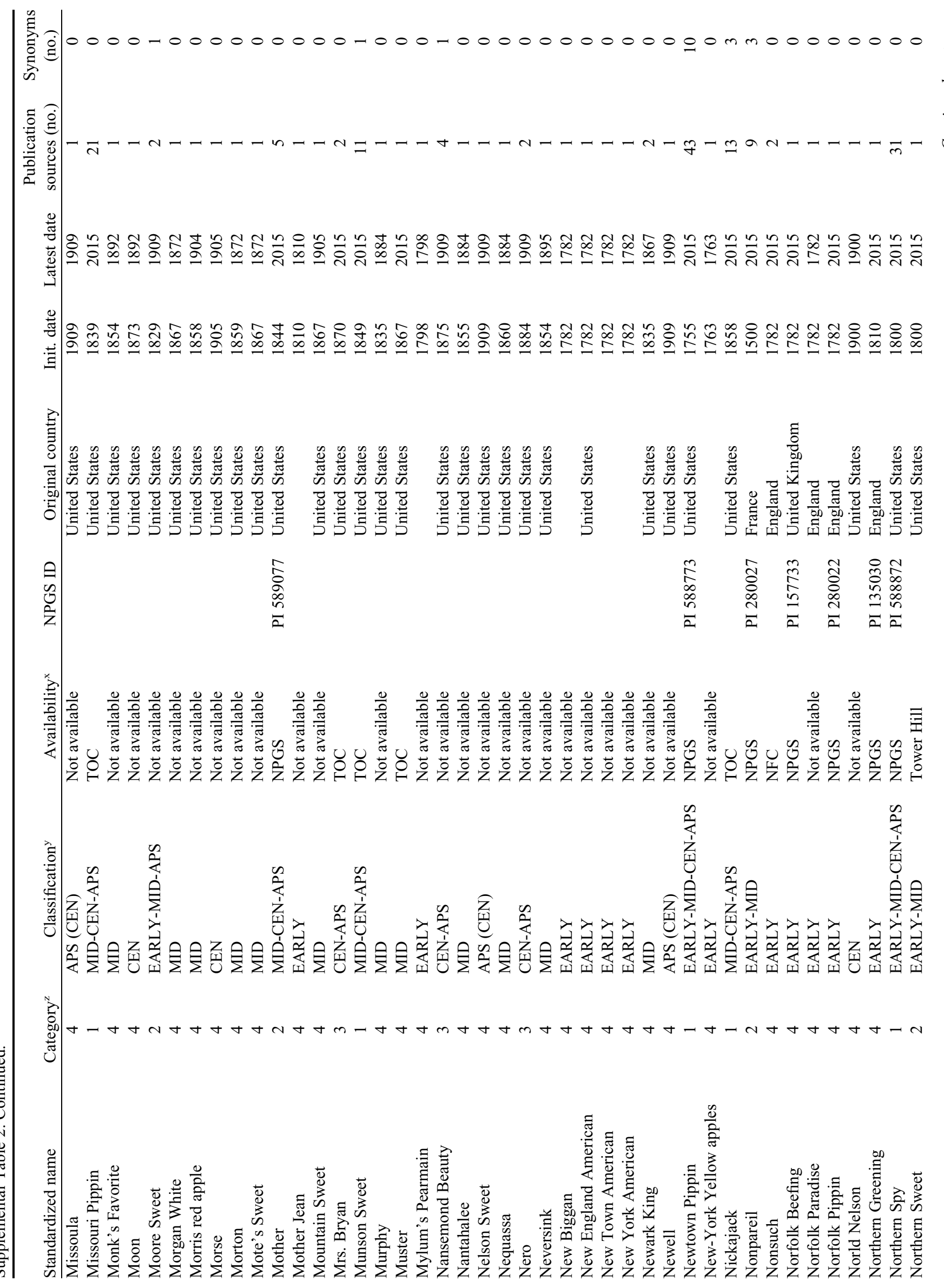




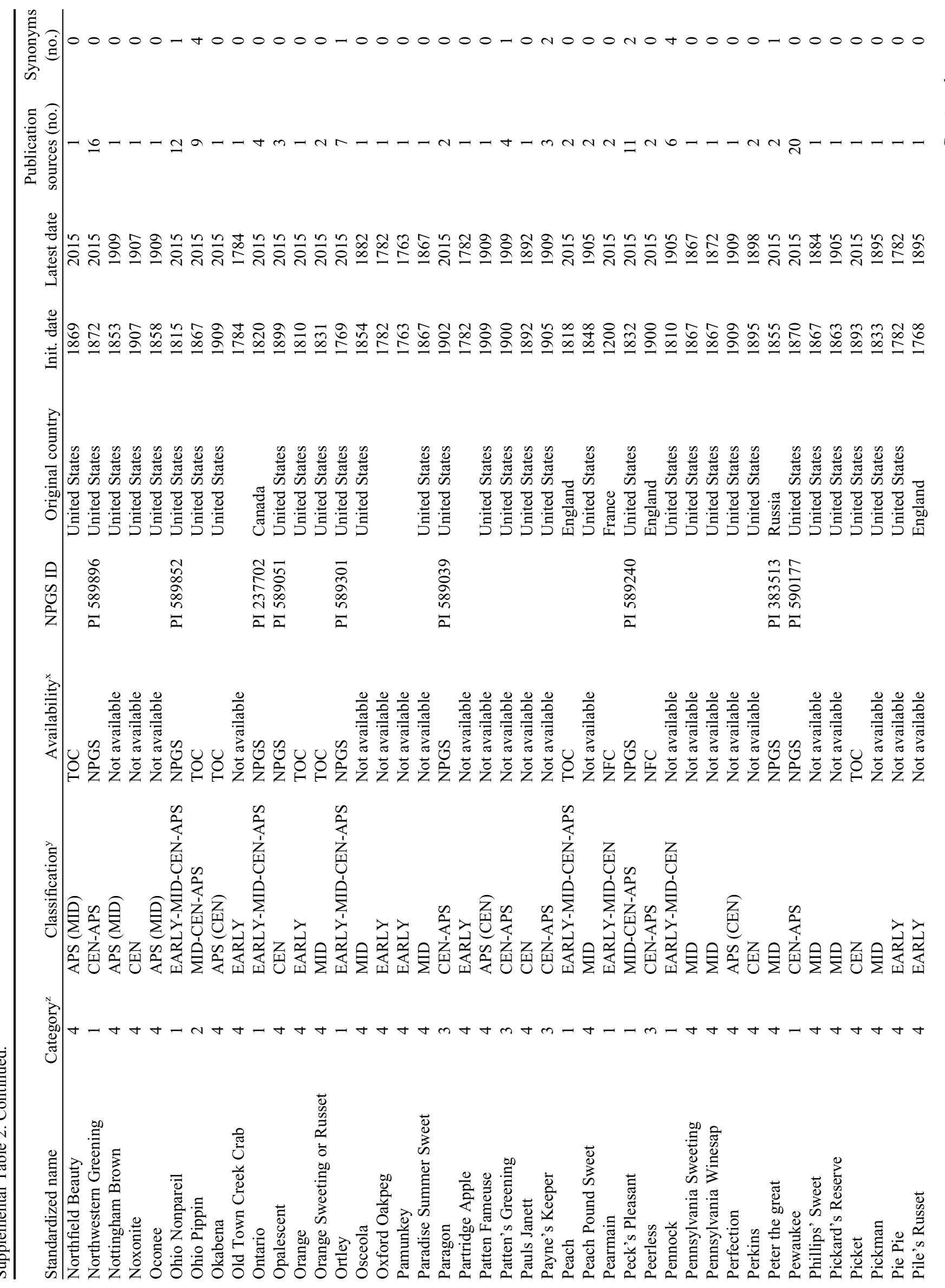




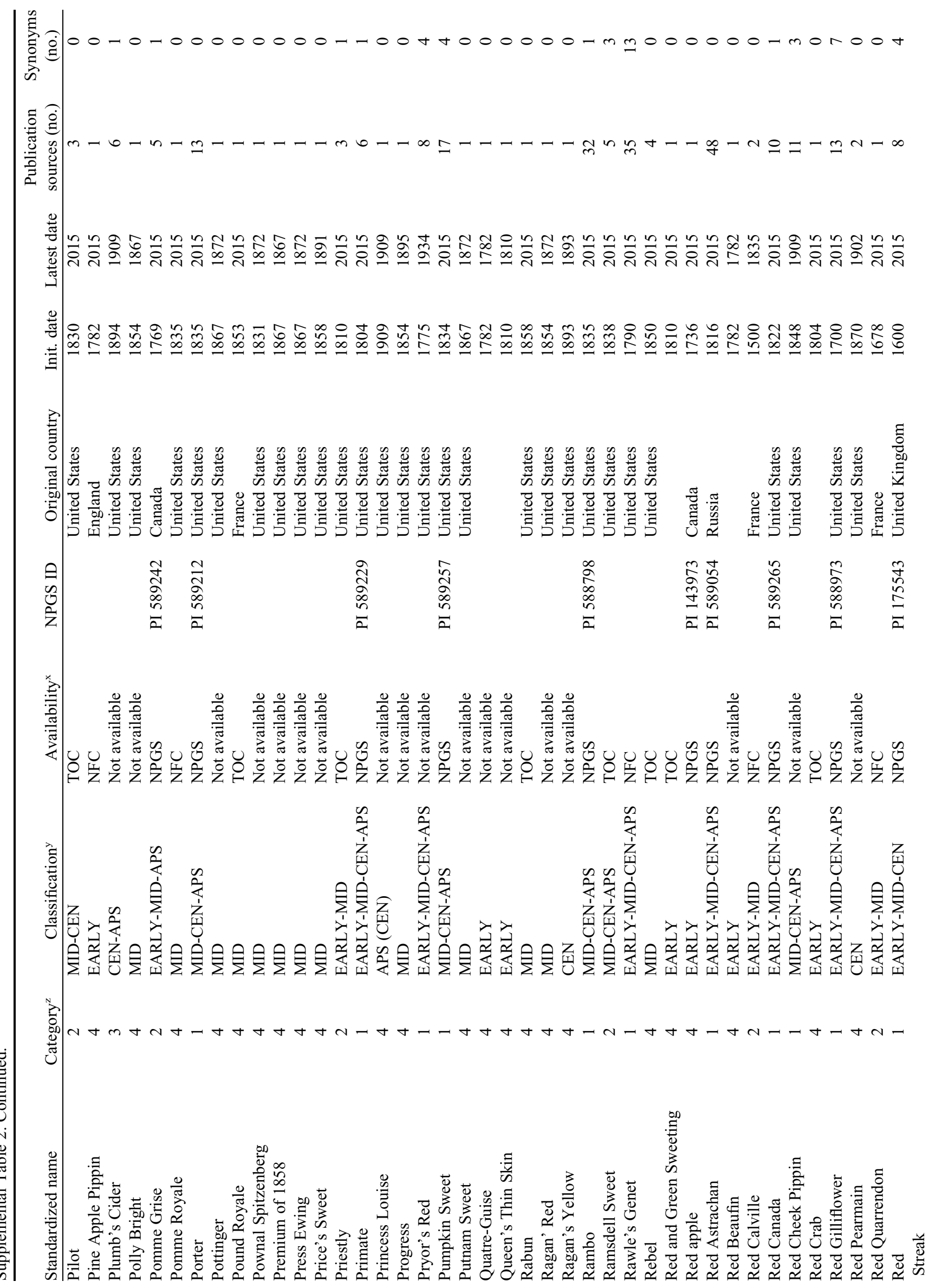




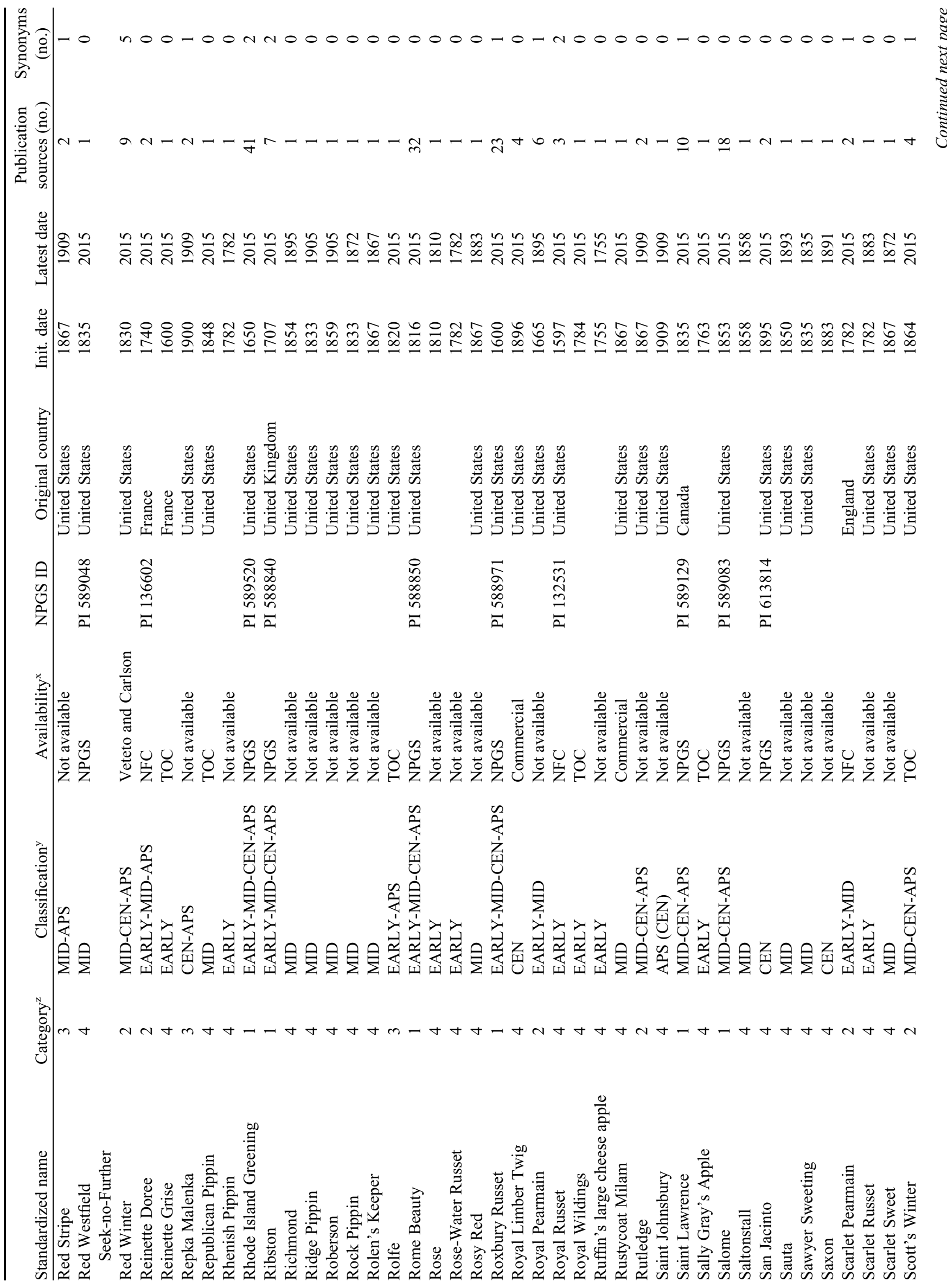




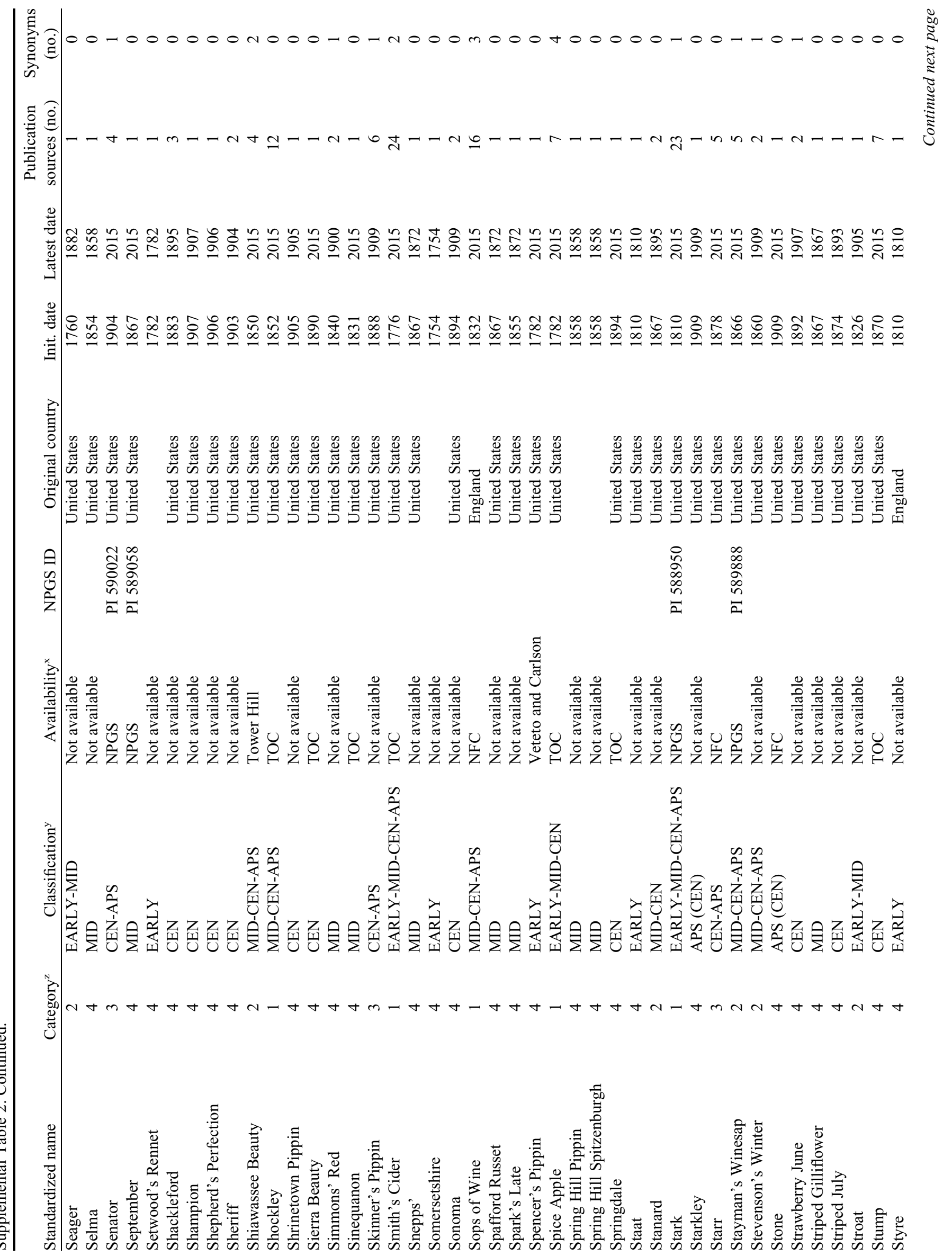




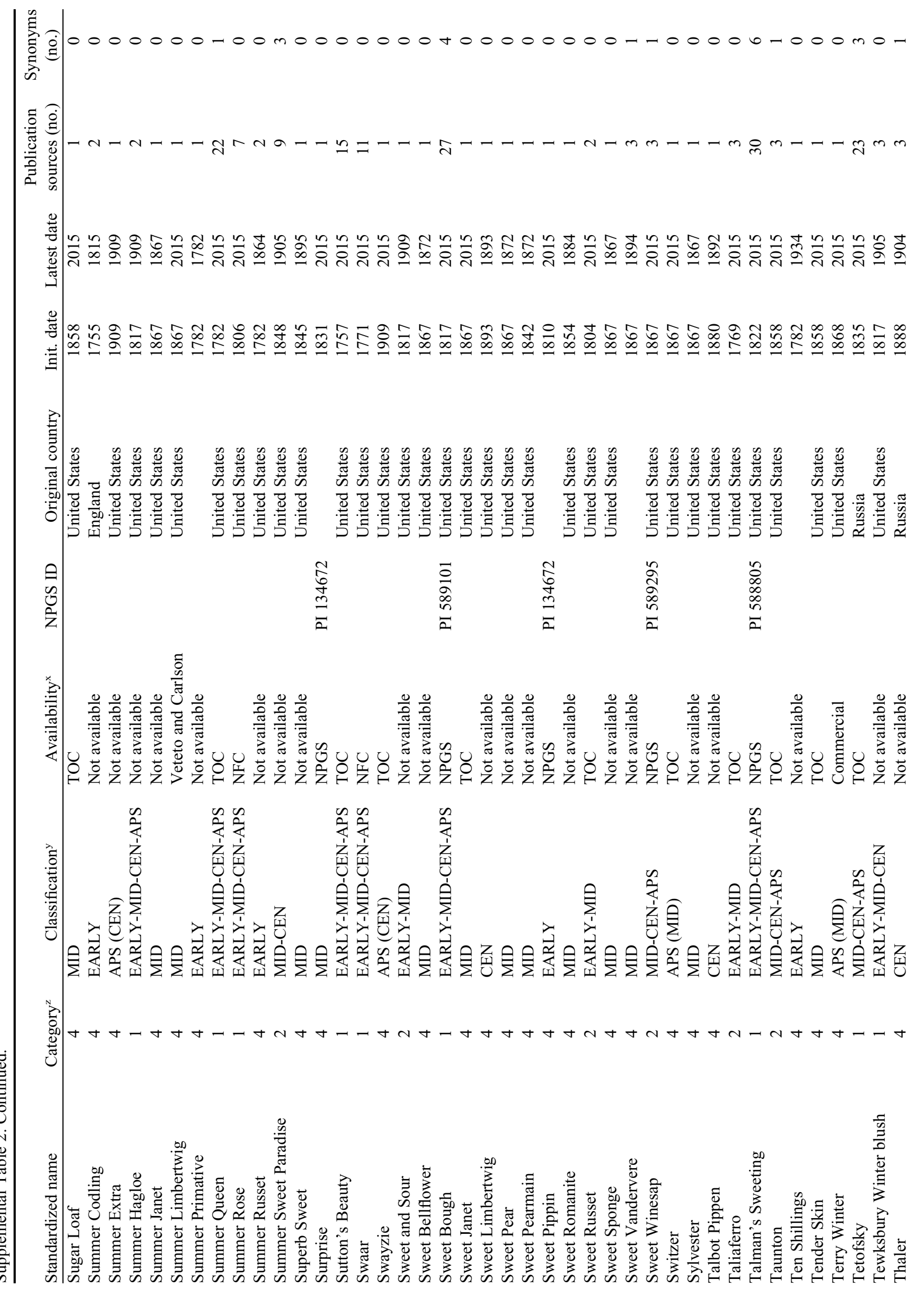




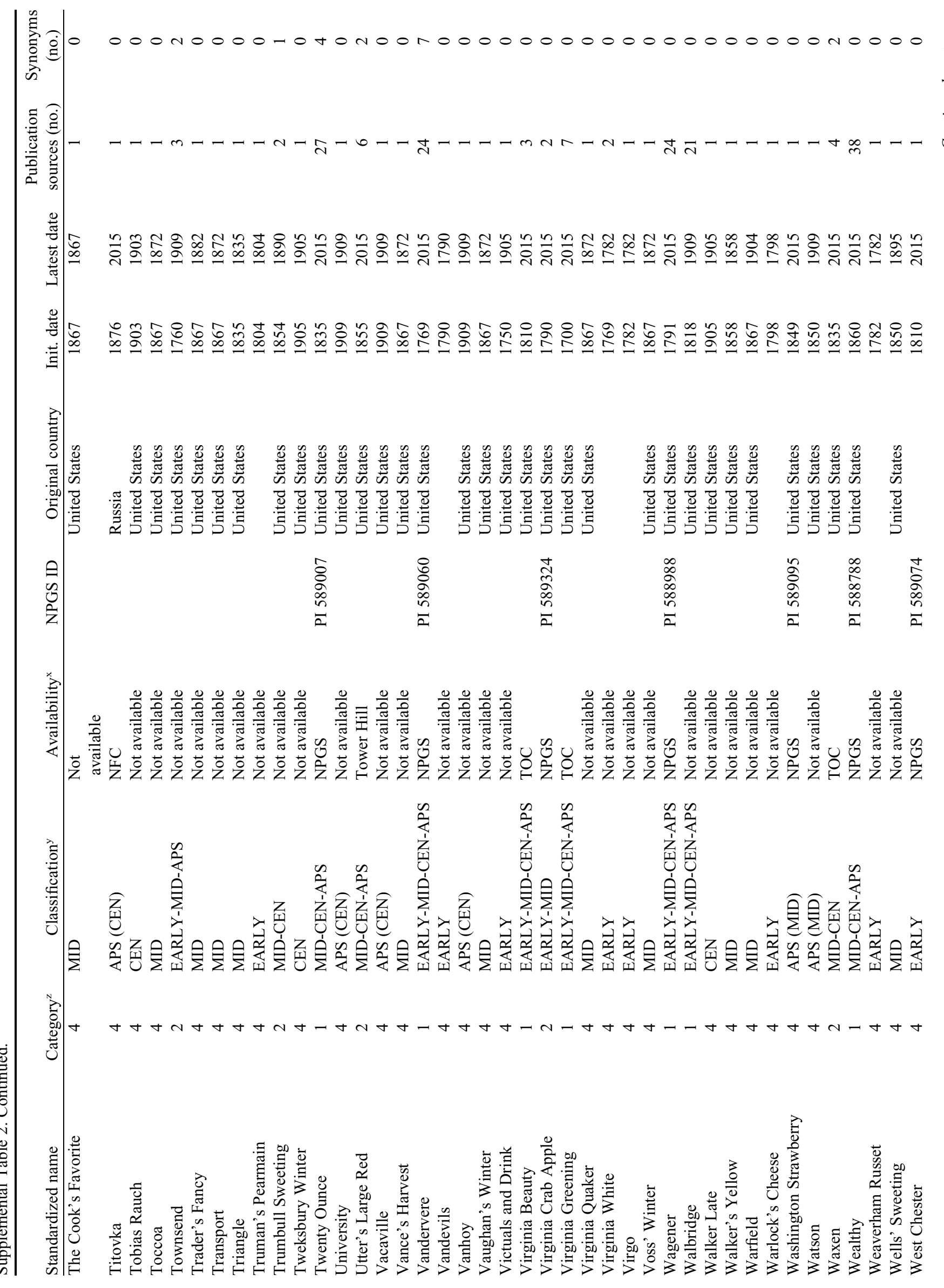




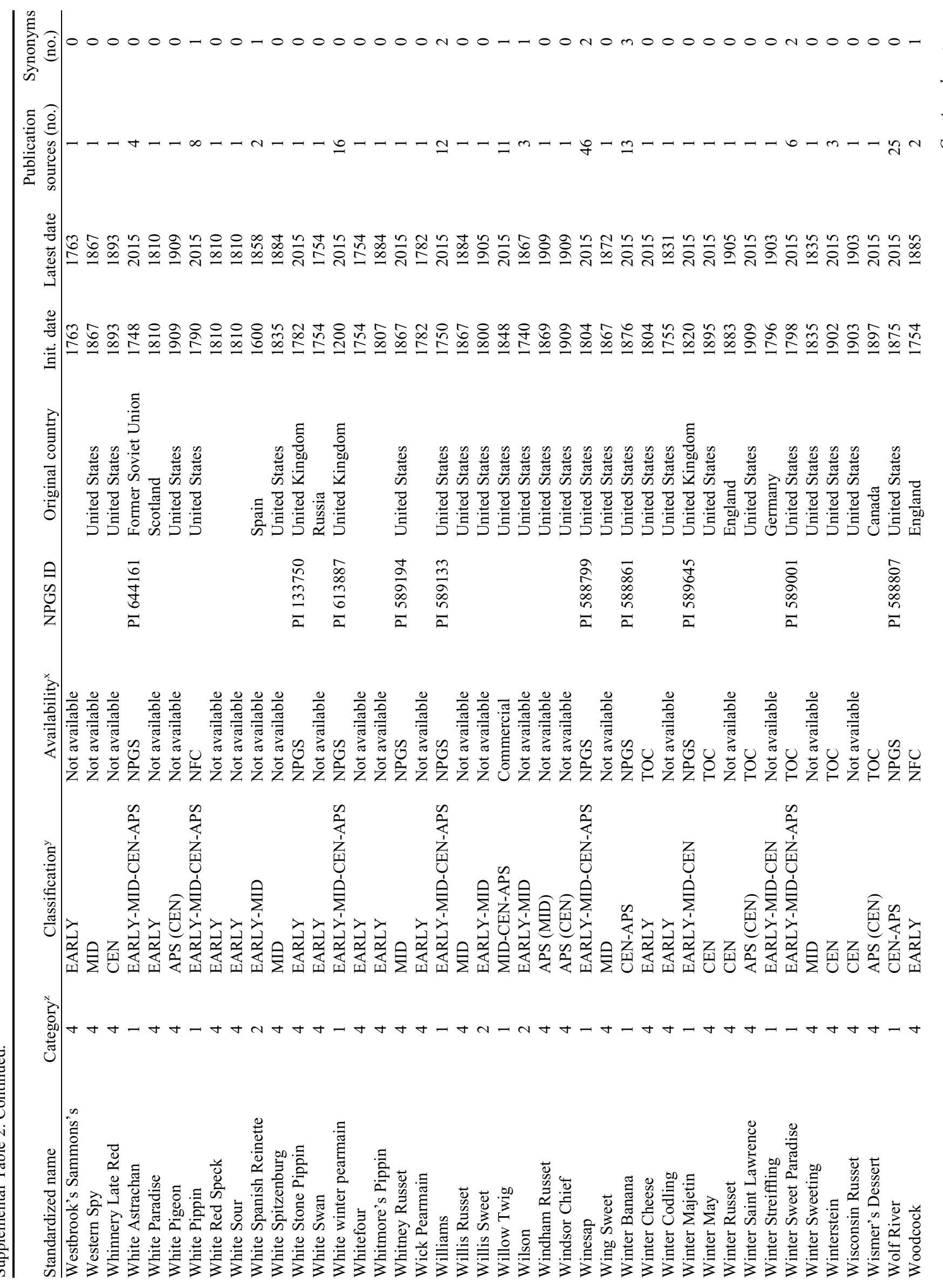




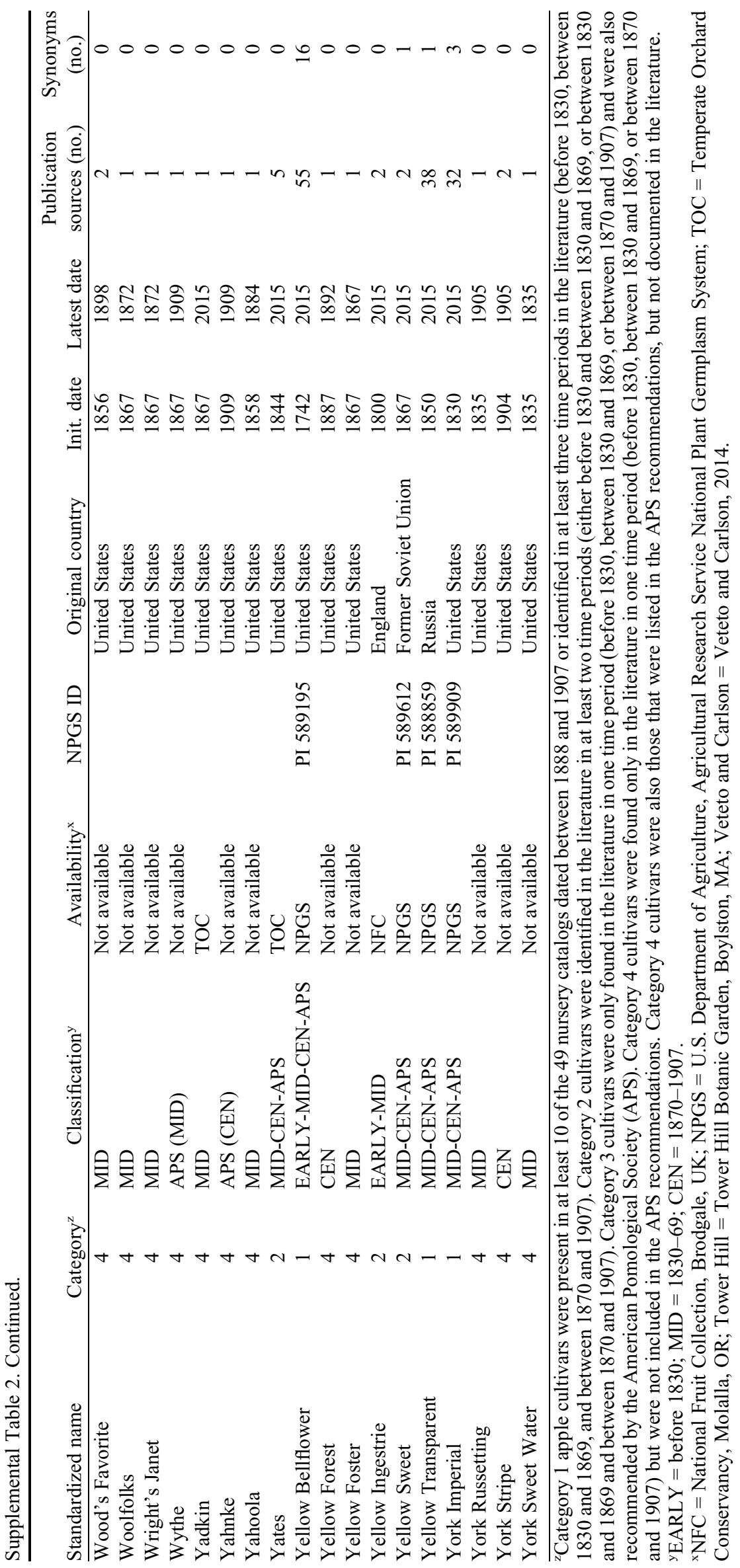

